\title{
The Social Costs of Electricity Generation-Categorising Different Types of Costs and Evaluating Their Respective Relevance
}

\author{
Sascha Samadi \\ Wuppertal Institute for Climate, Environment and Energy, Döppersberg 19, 42103 Wuppertal, Germany; \\ sascha.samadi@wupperinst.org; Tel.: +49-202-2492-107 \\ Academic Editor: Bin Chen \\ Received: 11 January 2017; Accepted: 9 March 2017; Published: 13 March 2017
}

\begin{abstract}
Various electricity generation technologies using different primary energy sources are available. Many published studies compare the costs of these technologies. However, most of those studies only consider plant-level costs and do not fully take into account additional costs that societies may face in using these technologies. This article reviews the literature on the costs of electricity generation technologies, aiming to determine which types of costs are relevant from a societal point of view when comparing generation technologies. The paper categorises the relevant types of costs, differentiating between plant-level, system and external costs as the main categories. It discusses the relevance of each type of cost for each generation technology. The findings suggest that several low-carbon electricity generation technologies exhibit lower social costs per $\mathrm{kWh}$ than the currently dominant technologies using fossil fuels. More generally, the findings emphasise the importance of taking not only plant-level costs, but also system and external costs, into account when comparing electricity generation technologies from a societal point of view. The article intends to inform both policymakers and energy system modellers, the latter who may strive to include all relevant types of costs in their models.
\end{abstract}

Keywords: electricity generation technologies; social costs; plant-level costs; system costs; external costs; literature review

\section{Introduction}

Access to electricity is widely regarded as a prerequisite for an appropriate standard of living and social integration [1], yet in 2014 almost 1.2 billion people still lacked this access [2]. At the same time, electrical appliances continue to grow in importance in the daily lives of billions of people. Consequently, the share of electricity in final energy demand has steadily grown over the past decades [3]. This trend is expected to continue in future decades as climate change mitigation strategies involve replacing fossil fuels with electricity in end-use applications [4-6]. Ensuring the sufficient provision of electricity generated by economically, environmentally and socially acceptable means will, therefore, continue to be an important objective for policymakers around the world.

Currently a large number of electricity and energy system models exist that aim to inform policymakers about the lowest cost solutions for meeting future electricity demand [7,8]. Policymakers may be interested in such analyses to "back the right horse" when deciding, for example, on public research, development and demonstration (RD\&D) expenses, energy infrastructure priorities or the level of financial support given to specific technologies. Models explicitly aiming to inform policymakers about the lowest cost evolution of electricity supply from a societal perspective should obviously strive to consider all types of electricity generation costs that are relevant to society (as opposed to taking into account, for example, only those types of costs that are relevant to investors). 
Based on an extensive literature review, this article seeks to provide a comprehensive overview of the current knowledge on the social costs of electricity generation. It identifies the relevant types of costs and makes suggestions about how to categorise these. More specifically, the article aims to emphasise the fact that not only plant-level costs, but also system and external costs, are relevant when assessing the costs of various types of electricity generation technologies from a societal perspective. Energy system modellers may be able to use the findings from this article to complement their models and to better understand the capabilities and limitations of their respective models in considering the total social costs of electricity generation.

For practical reasons, this article focuses on the social costs of electricity generation in Europe and the USA, as very little literature is available on social costs (especially system costs and external costs) in other world regions. It should, therefore, be kept in mind that some of the findings in this study are likely to be specific to electricity systems in industrialised countries and are not necessarily representative of the social costs of electricity generation in developing countries. Furthermore, due to the availability of the literature and to simplify inter-technology comparisons, this study focuses on medium to large-scale (i.e., utility-scale) applications of electricity generation technologies. The social costs of small-scale, decentralised electricity generation will differ to some extent. For example, while plant-level costs for decentralised systems tend to be higher than for centralised ones (due to economies of scale), transmission costs tend to be lower and local generators may put special emphasis on minimising external costs, such as air pollution and noise.

It should also be noted that this article does not discuss specific instruments that society or policymakers can use to ensure that the full social costs are taken into account by market actors. Such instruments include taxation, emission trading systems, subsidies and corporate social responsibility [9-12].

This article is structured as follows: Section 2 defines the term "social cost of electricity generation", which is the sum of the various types of costs grouped into the three main cost categories of plant-level costs, system costs and external costs. Section 3, the main section of this article, discusses the qualitative and quantitative findings from the literature for each type of differentiated cost. Based on these literature findings. Section 4 summarises the typical estimates of the various types of social costs for several electricity generation technologies. Finally, Section 5 concludes and suggests further areas of research.

\section{Defining and Categorising the Social Costs of Electricity Generation}

This article evaluates the cost to society of generating electricity using various technologies. In the field of economics, the cost of a good refers to the value of all the scarce resources that have been used to produce the good. This value, in turn, is measured in terms of the value of the next best good that could have been produced with the same resources, and is called opportunity cost [13]. In the remainder of this article, the social opportunity cost of generating electricity is being referred to when the terms "cost" or "social cost" are used.

Social costs are typically broken down into "private costs" and "external costs". The private costs of a good are those types of opportunity costs that are accrued by the market player who produces the good. These costs are taken into account by the producer when deciding on the production volume, and the producer's aim is to minimise these costs. External costs, on the other hand, can be defined as the costs arising from human activity that are not accounted for by the market player causing the externality [13]. For example, the particulate pollutants from a fossil fuel power plant causing negative health effects for people living near the plant are external costs. The power plant "uses" the scarce resource of health, without the costs being accrued by the market player who caused it.

It is argued here that when analysing the total social costs of electricity generation, it is useful to further differentiate private costs into the two categories of "plant-level costs" and "system costs". Plant-level costs encompass the private costs associated with electricity generation at the plant. These consist of capital costs, fuel costs, non-fuel operation and maintenance (O\&M) costs, and-if a carbon 
market is in place-carbon costs. These costs are frequently compared between different types of electricity generation technologies by calculating the "levelized cost of electricity" (LCOE).

System costs can be defined as all the costs associated with the reliable delivery, at the right time, of the electricity generated at plant-level to the locations where the electricity is needed. These costs include the costs of transmission and distribution networks, of storage technologies and of a range of so-called ancillary services required for the stable operation of an electricity system. Following [14], we also include "profile costs" within the system costs. Profile costs can be defined as the additional specific capital and operational costs that electricity generation from a new plant causes in the residual electricity system, as well as any overproduction costs of electricity generation from variable renewable energy (VRE) sources.

As system costs are often difficult to ascribe unequivocally to individual power plants, some of these costs are typically apportioned to electricity suppliers and/or consumers by regulatory entities, for example through tariffs per unit of electricity produced or consumed.

It could be argued that the sum of plant-level costs, system costs and external costs as defined in this article still does not encompass the total social costs of electricity generation. This is because the macroeconomic and geopolitical effects stemming from changes in the electricity system may have welfare effects beyond those reflected in the plant-level, system and external costs. For example, some electricity generation technologies may lead to greater levels of employment than others (on a per-kWh basis) and the creation of employment may be valued by society beyond the value attributed by the employer and the employee (and thus reflected in the employee's wage). Apart from employment effects, terms of trade effects and effects on the competitiveness of an economy are also discussed as possible relevant macroeconomic costs and benefits when comparing the total social costs of different electricity generation technologies. Finally, the choice of a primary energy source may also have geopolitical impacts, such as increased dependence on key natural gas or oil exporting countries.

While it is true that these potential macroeconomic and geopolitical effects are often relevant in energy policy discussions, it is extremely difficult to precisely quantify them or to determine how they differ between various electricity generation technologies. Due to these difficulties, and to focus more on the plant-level, system and external costs, it was decided not to include a discussion of macroeconomic and geopolitical costs and benefits in this literature review.

Figure 1 provides an overview of the cost categories that can be differentiated when determining the total social costs of electricity generation. It suggests that the definition of social costs as used in this article can be regarded as a definition in a narrower sense, as potential macroeconomic and geopolitical costs (and benefits) are not taken into account.

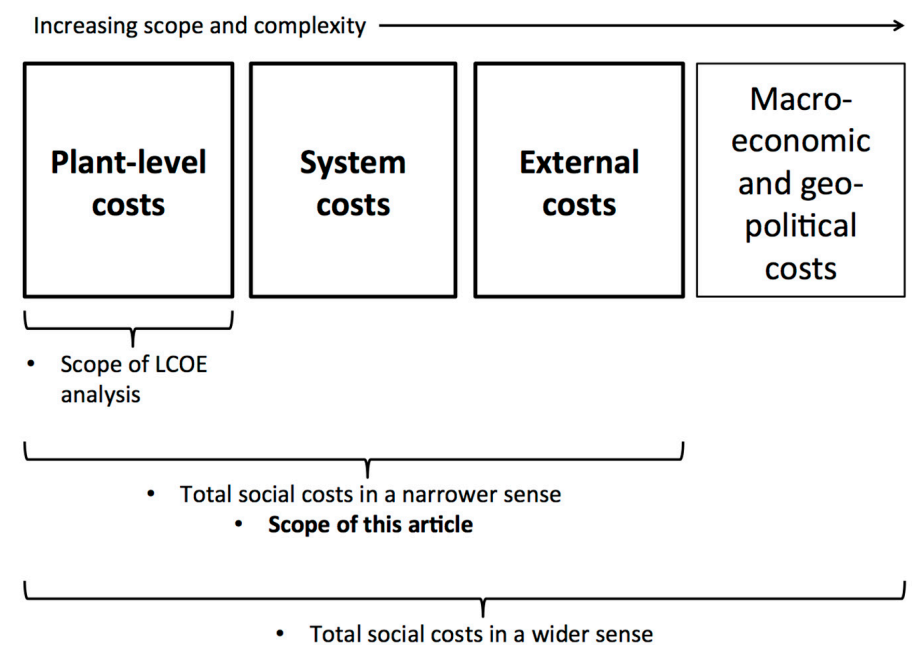

Figure 1. Overview of the main cost categories that can be differentiated when determining the total social costs of electricity generation. 
It should be noted that while this article only deals with the social costs of electricity generation, it is important to bear in mind that energy efficiency improvements can, in many cases, reduce electricity demand at very low social costs per kWh [15-17].

\section{Discussing the Individual Types of Social Costs of Electricity Generation}

As explained in the previous section, the three main categories of the social cost of electricity generation differentiated in this article are plant-level costs, system costs and market costs. Within each of these main cost categories, additional sub-categories of costs are distinguished. These sub-categories of costs have been identified based on an extensive review of the available literature on the plant-level, system and external costs of electricity generation. Table 1 provides an overview of the types of costs that have been found to be relevant for some, or all, electricity generation technologies. Based on the literature review, the following three subsections will discuss and evaluate the current state of knowledge on the plant-level costs (3.1), system costs (3.2) and external costs (3.3) of electricity generation technologies.

Table 1. Overview of the sub-categories of costs found to be relevant for comparing the social costs of electricity generation technologies.

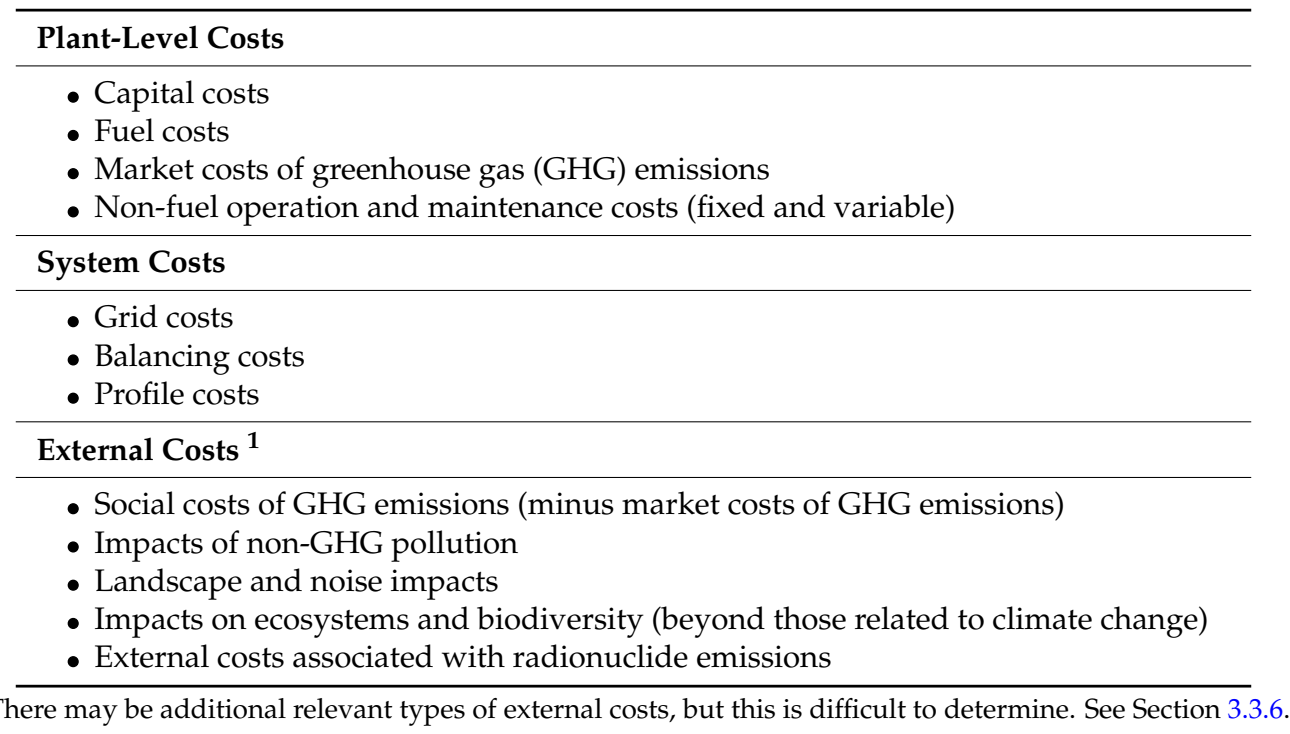

\subsection{Plant-Level Costs}

This section introduces and discusses the types of costs of electricity generation that accrue at plant-level and are reflected in the various markets. These types of costs are:

- Capital costs;

- Fuel costs;

- Market costs of greenhouse gas (GHG) emissions;

- Non-fuel operation and maintenance costs (fixed and variable).

\subsubsection{Capital Costs}

Capital costs comprise investment costs (including grid connection costs), refurbishment and decommissioning costs, as well as financing costs. As there are competitive markets for most energy technologies and their respective components, it can be assumed that market prices are a good indicator for the actual macroeconomic costs that accrue from manufacturing and installing these technologies (apart from external costs, which will be discussed in Section 3.3). 
The costs of connecting a power plant to the existing grid are usually included in capital costs, as a power plant developer usually needs to bear these costs $[18,19]$. In relation to the total capital costs (including connection costs), grid connection costs are usually low for fossil fuel and nuclear power plants, as well as for biomass and solar photovoltaic (PV) plants, with shares typically lower than $5 \%[20,21]$. However, connection costs can be more relevant for other types of plants, such as onshore and offshore wind power plants, as these are often built further away from existing grids and their locations can be difficult to access. According to [22], grid connection costs typically make up $10 \%$ to $12 \%$ of the capital costs for onshore plants and $21 \%$ to $23 \%$ for offshore plants.

Decommissioning costs are typically included in capital costs. Even though at the time of decommissioning these costs may be significant, especially for nuclear power plants, they only accrue at the very end of a plant's lifetime. In the LCOE methodology these decommissioning costs become negligible (around 1\% or less) once discounted at any commonly used rate: "For an investor [... ] contemplating an investment today, decommissioning costs are too far in the future and not a decisive criterion from a financial perspective" [23].

Capital costs are an important type of cost for every energy technology. Their share in total LCOE is around or above $60 \%$ for renewable, nuclear and coal carbon capture and storage (CCS) power plants. For conventional coal and natural gas power plants, fuel and $\mathrm{CO}_{2}$ costs are more important, especially at low discount rates [24].

\subsubsection{Fuel Costs}

It is difficult to determine to what extent the market costs for various fuels reflect their actual cost to society. For many of the fossil fuels produced globally, production costs are significantly lower than market prices, although the difference between production costs and prices is more pronounced for oil than for natural gas and coal (which are both more relevant in terms of electricity generation) [25]. These rents-captured by governments in taxes and royalties and by oil companies in profits-may be interpreted as an indication that market prices overestimate the global costs to society of using fossil fuels. On the other hand, these fuels are exhaustible resources, which means that the costs that accrue by using them include not only the extraction costs but also the opportunity cost of not being able to use the fuels at a later point in time [26]. However, this opportunity cost cannot be precisely quantified and it is unclear if, or to what extent, it is included in market prices.

For nuclear power, the waste management costs can be included within the fuel costs [24]. It should be mentioned that, like the decommissioning costs, there is also considerable uncertainty about the waste management costs of nuclear power plants.

The share of fuel costs in total plant-level costs varies considerably from technology to technology. While for many technologies using renewable energy sources no fuel costs accrue, the fuel cost share of natural gas power plants can be as high as around 70\% [24].

\subsubsection{Market Costs of GHG Emissions}

A number of regional, national and sub-national carbon pricing systems are currently in place, and these covered about 13\% of global GHG emissions in 2016 [27]. Although there are considerable differences between the various schemes, notably whether an emissions trading system or a carbon tax is used, they all share the key objective of reducing GHG emissions by assigning costs to them. This follows the insight from economic theory that internalising the costs of harmful emissions can efficiently reduce emissions to an acceptable level.

However, the existence of an emissions trading system or a carbon tax does not mean that the total costs accrued by society due to GHG emissions are actually internalised. While the social costs associated with GHG emissions are very difficult to determine for various reasons (see Section 3.3.1), they are widely assumed to be considerably higher than the current emissions costs in most carbon pricing schemes around the world. With the exception of a few schemes in Switzerland and Scandinavia, $\mathrm{CO}_{2}$-equivalent prices in carbon pricing schemes around the world are currently below 
$€ 25 /$ ton [27], although price increases beyond this level are expected in some regions in the early or mid-2020s [28,29]. In other words, the current costs of emitting $\mathrm{CO}_{2}$ in most regions of the world are too low to fully reflect the damage caused by these emissions.

For fossil fuel electricity generation technologies, $\mathrm{CO}_{2}$ prices can be decisive in determining their competitiveness. This is especially true for non-CCS coal power plants. At hypothetical $\mathrm{CO}_{2}$ costs of $€ 50 /$ ton, plant-level costs of hard coal power generation would be about $90 \%$ higher compared to a situation in which no carbon pricing was in place.

\subsubsection{Non-Fuel Operation and Maintenance Costs}

Non-fuel O\&M costs include fixed costs such as wages for the permanent plant staff and insurance costs, as well as routine equipment maintenance costs and variable costs for e.g., water, lubricants and energy used in auxiliaries.

The share of non-fuel O\&M costs varies from one technology to another. It is relatively low (around or below 10\%) for natural gas combined cycle gas turbine (CCGT) plants and conventional coal power plants and relatively high (around 25\%) for onshore and offshore wind plants [24]. It is assumed in this article that markets for O\&M services are generally operating normally and market prices for these services therefore reflect the full macroeconomic costs of their provision.

\subsubsection{Sum of Plant-Level Costs in the Form of Levelized Cost of Electricity (LCOE)}

Figure 2 provides an overview of the ranges of plant-level LCOE for selected types of newly-built power plants in Europe and the USA. For reasons of brevity, this subsection, as well as the social cost overview in Section 4, only discusses the three most prevalent types of conventional power plants (hard coal, natural gas CCGT and nuclear power plants) as well as onshore wind, offshore wind and solar PV. Wind and solar PV technologies are expected to play key roles in Europe and the USA in the coming decades $[4,6,30]$. The technological characteristics and LCOE ranges of other renewable generation technologies, such as hydropower, biomass, geothermal and solar thermal power plants, vary considerably and are therefore difficult to adequately discuss within the limited scope available here. For a detailed discussion of global and regional LCOE and their ranges, including for additional renewable energy technologies, readers are referred to $[21,24,31,32]$.

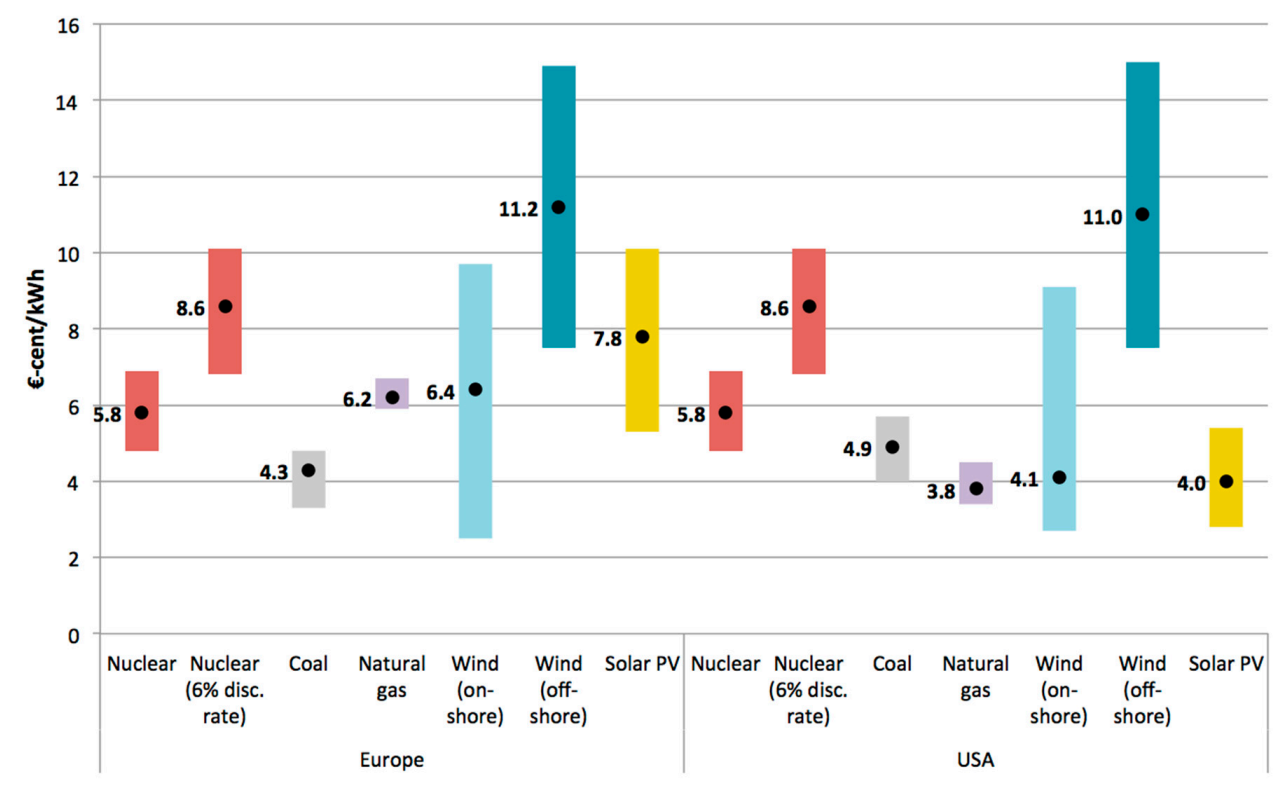

Figure 2. Plant-level LCOE ranges and central values (black dots) for selected types of newly-built power plants in Europe and the USA (w/o transmission costs and w/o costs of $\mathrm{CO}_{2}$ emissions) using a discount rate of 3\%. Sources: See detailed descriptions of LCOE calculations in the Supplementary Materials. 
Data from a number of recent studies and documents $[6,24,31,33-44]$ were used as input to calculate the LCOE. $\mathrm{CO}_{2}$ costs and transmission costs are not included, as in this article these types of costs are treated as "external costs" $\left(\mathrm{CO}_{2}\right.$ costs, see Section 3.3.1) and "system costs" (grid costs, see Section 3.2.1), respectively. The LCOE presented also exclude the effect of subsidies, as subsidies only affect private costs, not societal costs. The central values represent plants with average costs, while the ranges were derived by varying capital costs (for all technologies), full load hours (for onshore wind, offshore wind and solar PV), fuel cost developments (for coal and natural gas) and technical lifetime (for nuclear power) within the range of values typically observed or expected. The Supplementary Materials provide details on the LCOE calculations, listing all the relevant input parameters, as well as their respective sources.

For coal, natural gas and nuclear power plants, it is assumed they can operate in baseload mode (with a capacity factor of $85 \%$, following [24]). While such a capacity factor represents a value typically observed in electricity systems today, the expected further growth in electricity generation from variable renewable energy sources is likely to reduce the average capacity factors of conventional power plants in the future. As a sensitivity analysis, the International Energy Agency (IEA) [24] calculates the LCOE of baseload power plants at capacity factors of 50\%. It finds that, compared to a capacity factor of $85 \%$, the LCOE of natural gas-fired generation increases by $11 \%$, the LCOE of coal-fired generation by $23 \%$ and the LCOE of nuclear power generation by $54 \%$. However, higher LCOE costs from lower full load hours are regarded as "system costs" rather than "plant-level costs" in this article.

The LCOE calculations presented here are generally based on a discount rate of $3 \%$, which is considerably lower than the typical cost of capital to private investors who face the risks associated with individual projects. It is typically argued that from a social or system-planner perspective (as adopted in this article), low discount rates of around 3\% are more appropriate than market-observed discount rates. This is because society as a whole can effectively reduce the non-systematic risk that individual investors bear to zero by pooling risks across the entire population [45,46]. Lower discount rates lead to lower LCOE, with this effect being more pronounced for capital-intensive technologies, especially nuclear power plants, compared to plants with higher operational costs, such as natural gas [47].

However, society as a whole still faces specific risks with every investment made and it can be argued that these risks systematically differ from one type of electricity generation technology to another. Specifically, the risk of investing in small-scale technologies, such as wind and solar PV, with no fuel cost uncertainty and the opportunity to increase capacity in small steps is less risky than investing in large-scale power plants, such as large fossil fuel and nuclear power plants [48]. Natural gas power plants, in particular, exhibit fuel cost uncertainty, while nuclear and coal power plants need to achieve high full load hours over several decades to become worthwhile investments. Unexpectedly low future electricity demand or unexpectedly high future investments in power plants with lower variable costs, such as wind turbines and solar PV plants, could impede such high full load hours, which would significantly increase the LCOE of nuclear and/or coal power plants.

Concerning nuclear power, there is the additional risk that in the decades following a power plant investment, a society may put greater emphasis on the inherent risks associated with this technology; for example, because of a large-scale nuclear accident elsewhere or because of a change in the perceived threats faced from terrorism or warfare. This may result in a society deciding to stop operating these plants, possibly well ahead of the end of their technical lifetime, again leading to higher LCOE.

A detailed quantitative reflection of these uncertainties is difficult and beyond the scope of this article. Instead, the higher investment risks associated with large-scale power plants are assumed to be captured by applying a higher discount rate of $6 \%$ for these plants. As the differences in investment risks may, in the future, be most relevant when comparing the low-carbon options of renewable energy technologies on the one hand with nuclear power plants on the other hand, the LCOE calculations in Figure 2 include a separate cost range for nuclear power plants using a discount rate of $6 \%$ instead of $3 \%$. (For reasons of brevity, the respective ranges for the fossil fuel plants are not shown.) 
The ranges in Figure 2 show that, even within Europe and the USA, the LCOE can vary considerably, especially for renewable energy technologies. This is due, among other things, to differences in the location of plants, their sizes and their technological characteristics. The considerable differences between Europe and the USA in the central LCOE values for onshore wind, solar PV and natural gas CCGT plants are mainly explained by the generally stronger wind, higher solar irradiation and the lower cost of natural gas in the USA.

In Europe, typical plant-level LCOE is lowest for coal power plants at $4.3 €$-cent $/ \mathrm{kWh}$, although onshore wind can be less expensive at good locations. The central LCOE estimates for nuclear power (at a 3\% discount rate, i.e., not reflecting higher risks), natural gas and onshore wind are similar, around $6 €$-cent/kWh. In the USA, typical current plant-level costs are lowest for natural gas, solar PV and onshore wind, all at similar costs of around $4 €$-cent $/ \mathrm{kWh}$. The plant-level costs of offshore wind power plants are typically considerably higher than for all the other analysed technologies in both Europe and the USA. However, the results of several auctions held in 2016 in Europe for constructing offshore wind farms suggest that the combined effect of, among other things, technological and operational advances, increased competition, larger turbines and larger wind farms has recently led to typical offshore wind power costs being closer to the lower end of the offshore wind cost ranges shown in Figure 2 [49].

\subsection{System Costs}

System costs comprise the costs of integrating an individual power plant into an existing electricity system. Based on the available literature, Figure 3 provides an overview of a possible differentiation between three components of system costs.

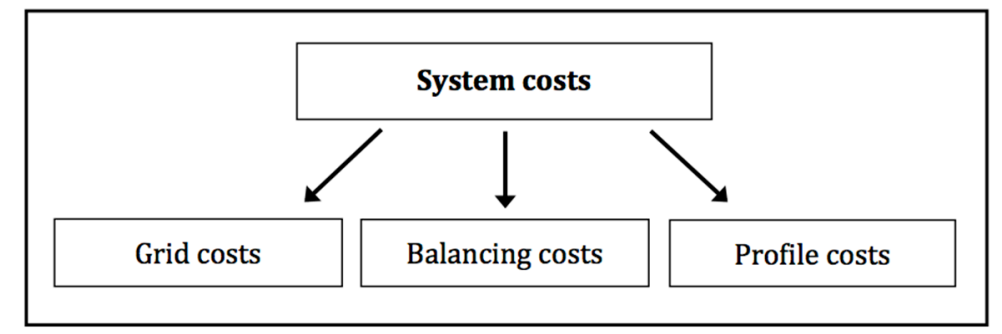

Figure 3. Three components of system costs. Sources: Based on [50,51].

While in recent years a growing body of literature has emerged discussing the various elements of system costs as depicted in Figure 3, there is currently no consensus on the precise definition of the term "system costs" and on the terms to be used for its individual components. This is particularly relevant for the cost component referred to in this article as "profile costs". These costs (or parts thereof) are also referred to in the literature as "backup costs", "adequacy costs", or (costs of the) "utilization effect". In this article, the definition of profile costs as provided by $[14,51]$ is applied.

A plant's system costs vary considerably from case to case, depending not only on the type of plant, but also on the plant's location and on various characteristics of the electricity system into which it is to be integrated [52]. Therefore, only approximate figures or ranges for specific system costs can be assigned to the various types of generation technologies. Furthermore, available studies attempting to quantify system costs (or individual components of these costs) deal with electricity systems in either Europe or North America. There is currently a lack of analysis of system costs in other regions of the world, especially in developing countries, "where integration issues may be very different from in OECD countries" [50].

Studies quantifying system costs deal almost exclusively with VRE plants as, in general, their system costs can be expected to be much more relevant than the respective costs of non-variable sources. As Hirth [53] notes, this is due to the intrinsic technological properties of VRE technologies. 


\subsubsection{Grid Costs}

Grid costs, or more precisely "grid reinforcement and extension costs", can be defined as the extra costs in the transmission and distribution system when power generation from a new plant is integrated into that system [54]. It can be argued that only a part of the extra costs should be allocated to the new plant, as other electricity producers may also benefit from the required grid reinforcements and extensions, for example through increased grid stability $[50,55,56]$.

The specific grid costs of a new power plant—despite being difficult to establish precisely-may vary considerably from one case to another, with several factors determining these costs. Among these factors are the proximity of a new plant to the existing transmission grid, its distance to load centres, its capacity factor, the extent and quality of the existing grid and the lifetime of the transmission investments [50].

Research on grid reinforcement and extension costs in recent years has focused on costs associated with the expanded use of renewable energy sources, especially wind. Table 2 provides an overview of the specific grid costs of different electricity generation technologies at varying penetration rates as provided by several studies.

Table 2. Additional specific grid costs of different electricity generation technologies at varying penetration rates according to several studies.

\begin{tabular}{|c|c|c|c|c|c|}
\hline Source & $\begin{array}{l}\text { Country or } \\
\text { Region }\end{array}$ & Technology & $\begin{array}{l}\text { Penetration Rate } \\
\text { (Share of Total } \\
\text { Electricity } \\
\text { Generation) }\end{array}$ & $\begin{array}{c}\text { Grid Costs } \\
\text { (in } € \text {-cent/kWh) }\end{array}$ & Comments \\
\hline $\begin{array}{c}\text { [57 }^{1} \\
\text { (meta-study) }\end{array}$ & USA & $\begin{array}{l}\text { Wind (onshore } \\
\text { and offshore) }\end{array}$ & $\begin{array}{l}\text { Not provided } \\
\text { (varying) }\end{array}$ & 1.4 & Median; full range: $0-7.2$ \\
\hline $\begin{array}{c}{[54]} \\
\text { (meta-study) }\end{array}$ & $\begin{array}{l}\text { Six European } \\
\text { countries }\end{array}$ & $\begin{array}{l}\text { Wind (onshore } \\
\text { and offshore) }\end{array}$ & $\approx 10 \%-60 \%$ & $\approx 0.4$ & $\begin{array}{l}\text { Median; full range: } \approx 0.2-1.1 \\
\text { Original data in } € / \mathrm{kW} \text {; conversion } \\
\text { assumes } 2000 \text { full load hours per year, } \\
\text { a discount rate of } 7 \% \text { and a grid } \\
\text { lifetime of } 40 \text { years } \\
\text { No clear correlation between specific } \\
\text { grid costs and penetration level }\end{array}$ \\
\hline \multirow{4}{*}[58]{$^{1}$} & \multirow{4}{*}{$\begin{array}{l}\text { Six OECD } \\
\text { countries }\end{array}$} & Wind (onshore) & $\begin{array}{l}10 \% \\
30 \%\end{array}$ & $\begin{array}{l}0.2 \\
0.3\end{array}$ & $\begin{array}{l}\text { Median; full range: }<0.1-0.3 \\
\text { Median; full range: } 0.2-2.0\end{array}$ \\
\hline & & Wind (offshore) & $\begin{array}{l}10 \% \\
30 \%\end{array}$ & $\begin{array}{l}0.1 \\
0.2\end{array}$ & $\begin{array}{l}\text { Median; full range: }<0.1-0.2 \\
\text { Median; full range: }<0.1-1.1\end{array}$ \\
\hline & & Solar PV & $\begin{array}{l}10 \% \\
30 \%\end{array}$ & $\begin{array}{l}0.4 \\
0.5\end{array}$ & $\begin{array}{l}\text { Median; full range: }<0.1-0.5 \\
\text { Median; full range: } 0.2-4.3\end{array}$ \\
\hline & & Nuclear, coal, gas & $10 \%$ and $30 \%$ & 0 & - \\
\hline [59] & $\begin{array}{l}\text { Eleven } \\
\text { European } \\
\text { countries }\end{array}$ & Solar PV & $15 \%$ to $18 \%$ & 1.2 & $\begin{array}{l}\text { Maximum; lower in some countries; } \\
\text { only distribution grid and } \\
\text { cross-country transmission lines } \\
\text { taken into account }\end{array}$ \\
\hline$[60]$ & Australia & $\begin{array}{c}\text { CSP }^{2} \\
\text { (with storage) } \\
\text { Geothermal } \\
\text { Biomass } \\
\text { Coal CCS }\end{array}$ & $18 \%-23 \%$ & $\begin{array}{l}0.3 \\
<0.1 \\
<0.1\end{array}$ & - \\
\hline
\end{tabular}

${ }^{1}$ Cost data in these studies is provided in USD. The costs were converted to EUR by using a conversion rate of

$1 \mathrm{EUR}=1.1 \mathrm{USD}{ }^{2}$ Concentrating solar thermal power.

\subsubsection{Balancing Costs}

The stable operation of an electricity system requires electricity demand and electricity supply to be equal at all times. Electricity systems therefore require a central system operator who ensures that unplanned (and thus unpredictable) short-term fluctuations in both electricity demand and supply can be compensated by contracting sufficient reserves ahead of time. These reserves are used if needed to provide balancing power [61]. 
The need to hold such reserves has cost implications as, overall, this requires greater capacity compared to a hypothetical system in which demand and supply are perfectly predictable and any kind of system failure can be ruled out. Additional fuel costs (and the related emissions costs) also accrue, as plant efficiency is typically lower when a plant—-to provide reserve capacity-is running below its full capacity and/or needs to ramp up and down frequently. Furthermore, frequent ramping may also negatively affect a plant's reliability and reduce its lifetime [62].

All types of power plants experience both planned and unplanned outages, so to a certain extent balancing costs can be attributed to all types of power plants. However, using VRE sources to generate electricity, as in the case of wind and solar PV power plants, generally leads to higher balancing requirements. As power generation from these sources is considerably more variable, less predictable and less controllable than power generation from other sources, these sources force other power plants in the system to change their output more rapidly and/or more frequently to maintain the balance between demand and supply [50,58]. Table 3 provides an overview of the specific balancing costs of different electricity generation technologies at varying penetration rates as provided by various studies.

Table 3. Additional specific balancing costs of different electricity generation technologies at varying penetration rates according to several studies.

\begin{tabular}{|c|c|c|c|c|c|}
\hline Source & $\begin{array}{l}\text { Country or } \\
\text { Region }\end{array}$ & Technology & $\begin{array}{l}\text { Penetration Rate } \\
\text { (Share of Total } \\
\text { Electricity } \\
\text { Generation) }\end{array}$ & $\begin{array}{c}\text { Balancing } \\
\text { Costs } \\
\text { (in } € \text {-cent } / \mathbf{k W h} \text { ) }\end{array}$ & Comment \\
\hline \multirow{2}{*}{ [58] } & \multirow{2}{*}{$\begin{array}{l}\text { Six OECD } \\
\text { countries }\end{array}$} & Nuclear & $\begin{array}{l}10 \% \\
30 \%\end{array}$ & $\begin{array}{l}<0.1 \\
<0.1\end{array}$ & - \\
\hline & & $\begin{array}{l}\text { Wind (onshore and } \\
\text { offshore) and solar PV }\end{array}$ & $\begin{array}{l}10 \% \\
30 \%\end{array}$ & $\begin{array}{l}0.3 \\
0.5\end{array}$ & $\begin{array}{l}\text { Median; full range: } 0.2-0.7 \\
\text { Median; full range: } 0.5-1.3\end{array}$ \\
\hline$[63]^{1}$ & Arizona, USA & Solar PV & $8 \%$ & 0.2 & Median, full range: $0.2-0.3$ \\
\hline $\begin{array}{c}{[64]} \\
\text { (meta-study) }\end{array}$ & $\begin{array}{l}\text { USA and several } \\
\text { European } \\
\text { countries }\end{array}$ & $\begin{array}{l}\text { Wind (onshore and } \\
\text { offshore) }\end{array}$ & $\begin{array}{l}\approx 10 \% \\
\approx 20 \% \\
\approx 30 \%\end{array}$ & $\begin{array}{l}0.3 \\
0.3 \\
0.4\end{array}$ & $\begin{array}{l}\text { Median; full range: }<0.1-0.4 \\
\text { Median; full range: }<0.1-0.5 \\
\text { Median; full range: } 0.1-0.6\end{array}$ \\
\hline [59] & $\begin{array}{l}\text { Eleven European } \\
\text { countries }\end{array}$ & Solar PV & $15 \%$ & 0.1 & - \\
\hline $\begin{array}{c}{[14]} \\
\text { (meta-study) }\end{array}$ & $\begin{array}{l}\text { Several European } \\
\text { countries and } \\
\text { several regions of } \\
\text { the USA }\end{array}$ & $\begin{array}{l}\text { Wind (onshore and } \\
\text { offshore) }\end{array}$ & $\approx 1 \%$ to $40 \%$ & $\approx 0.3$ & $\begin{array}{c}\text { Median, full range: }<0.1-1.3 \\
\text { No clear correlation between } \\
\text { specific balancing costs and } \\
\text { penetration level }\end{array}$ \\
\hline
\end{tabular}

There is little information in the literature on the balancing costs of dispatchable electricity generation. However, these costs can be expected to be considerably lower than the respective costs of VRE power plants. Keppler and Cometto [58] estimate the balancing costs of nuclear power plants to be less than $0.1 €$-cent $/ \mathrm{kWh}$.

\subsubsection{Profile Costs}

Largely following [14,51], profile costs can be defined as the additional specific capital and operational costs that electricity generation from a new plant may cause in the residual electricity system, plus overproduction costs of VRE electricity generation (see Figure 4).

Integrating new power plants into an existing system typically leads to increases in the specific costs of the residual power generation, i.e., the power generation of the existing plants still required after the integration of the new power plants. Any additional electricity generation, all other things being equal, leads to lower average full load hours of the existing plants, which in turn leads to higher specific generation costs. However, for conventional baseload, mid-merit or peak load plants, these costs do not or no longer accrue if or once corresponding old power plant capacities 
are decommissioned. Therefore, the literature typically focuses on new VRE power generation when discussing profile costs.

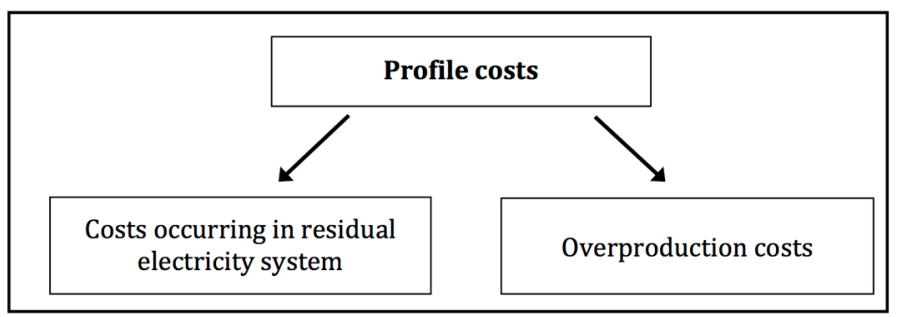

Figure 4. Two components of profile costs. Sources: Based on $[14,51]$.

Higher specific capital costs typically accrue when adding VRE technologies, as these are unable, or only marginally able, to reliably contribute to covering peak electricity demand. Consequently, the conventional generating capacity needed to reliably cover peak demand at all times remains (almost) unchanged as VRE technologies are added [50]. At the same time, these dispatchable plants become utilised for fewer hours per year, so their specific capital costs are higher than they would be without the VRE electricity generation [65].

Higher specific operational costs, due to the higher use of mid-merit and the lower use of baseload power plants, typically accrue as an increase in electricity generation from new VRE power plants leads to changes in the cost-optimal mix of the remaining power generation. The reason for this is the fluctuating nature of VRE power generation. Due to this fluctuation, fewer residual power plants can generate electricity "around the clock" and these power plants are typically the ones with lower operational costs [65]. Hirth et al. [14] point out that the steeper gradients of residual load resulting from VRE power generation also leads to higher operational costs of thermal power plants, as their output needs to follow steeper gradients. This causes additional ramping and cycling costs. Note that these costs only refer to scheduled ramping and cycling, while the costs of uncertainty-related ramping and cycling are reflected in balancing costs.

It should be noted that in certain circumstances, additional electricity generation from VRE sources may decrease the average capital and/or operational costs of the remaining electricity generation. A prominent example is the expansion of power generation from solar PV plants in regions in which there is a high correlation between solar PV output and peak electricity demand. In such cases, the need to operate expensive peaking plants is reduced as solar PV output increases, up to the point a certain solar PV penetration rate is reached [66]. Another example is the deployment of a certain amount of wind turbines in electricity systems with high shares of hydropower and seasonal complementarity between wind and hydrological resources [67,68]. Furthermore, the IEA [50] notes that in cases of small electricity systems needing additional capacity because of growing peak demand, small, optimally-sized VRE power plants may incur smaller capacity costs than conventional power plants. This can occur when there is a mismatch between the additional capacity needed and the smallest conventional plant that can be operated efficiently.

For any given amount of new VRE electricity generation, profile costs are lower in the long term than in the short term as, over time, the residual power plant structure adapts to the requirements brought about by the new VRE power generation, leading to a higher share of peak-load power plants which exhibit lower costs at low capacity factors. Furthermore, electricity demand can also be expected to adjust in the longer term. For example, if over several decades the combined share of solar PV and wind electricity generation increases from an insignificant value to $50 \%$ or $70 \%$, market forces-possibly supported by government regulations-are likely to lead to greater flexibility in electricity demand (aided by new and flexible demand sources such as electric vehicles and heat pumps). Such shifts can reduce peak demand and help balance the residual electricity demand, thus mitigating profile costs. 
While there is general agreement that additional VRE electricity generation typically leads to additional costs in the residual electricity system, there is no consensus on whether these costs should be attributed partially or wholly to the new VRE power plants. It could be argued, for example, that the real problem is the inflexibility of the existing power plants or, more generally, "that system adaptation inherently occurs in power systems and thus cannot be attributed directly to specific new technologies" [69].

According to [14,51], profile costs consist not only of the additional costs accrued in the residual electricity system but also include the costs of VRE overproduction. Overproduction costs-typically only relevant at higher VRE shares-are the opportunity costs of not being able to use all the electricity that could, in principle, be generated at zero marginal cost by a VRE plant, because demand and/or transmission capacity at any given point in time is insufficient.

Table 4 lists the findings of three studies examining the long-term profile costs caused by adding wind and/or solar PV power generation. It should be noted that $[14,65]$ do not include overproduction costs in their estimates. As specific profile costs generally increase when the share of VRE generation increases, average and marginal profile costs usually differ for specific VRE shares. Table 4 therefore differentiates between average and marginal specific profile costs. Some studies report only the former, while others report only the latter. The two studies in Table 4 reporting marginal costs also allow for an estimate of the average profile costs, so both values are provided.

Table 4. Average and marginal specific profile costs from wind and solar PV electricity generation according to several studies.

\begin{tabular}{|c|c|c|c|c|c|c|}
\hline \multirow{2}{*}{ Source } & \multirow{2}{*}{ Method Used } & \multirow{2}{*}{$\begin{array}{c}\text { VRE } \\
\text { Technology }\end{array}$} & \multirow{2}{*}{$\begin{array}{c}\text { Penetration } \\
\text { Rate (Share of } \\
\text { Total Electricity } \\
\text { Generation) }\end{array}$} & \multicolumn{2}{|c|}{$\begin{array}{c}\text { Profile Costs } \\
\text { (in } € \text {-cent/kWh } / h_{\text {VRE }} \text { ) }\end{array}$} & \multirow{2}{*}{ Comment } \\
\hline & & & & Average & Marginal & \\
\hline \multirow{6}{*}[51]{$^{1}$} & \multirow{6}{*}{$\begin{array}{l}\text { Generic modelling } \\
\text { (typical for European } \\
\text { countries with mainly } \\
\text { thermal power plants) }\end{array}$} & & $10 \%$ & 1.5 & 1.9 & \multirow{6}{*}{$\begin{array}{l}\text { VRE curtailment costs } \\
\text { included }\end{array}$} \\
\hline & & Wind & $20 \%$ & 1.9 & 2.5 & \\
\hline & & & $40 \%$ & 2.5 & 4.6 & \\
\hline & & & $10 \%$ & 1.5 & 2.7 & \\
\hline & & Solar PV & $15 \%$ & 2.1 & 3.3 & \\
\hline & & & $25 \%$ & 3.3 & 9.8 & \\
\hline \multirow{9}{*}[65]{$^{2}$} & \multirow{9}{*}{$\begin{array}{c}\text { Generic modelling } \\
\text { (based on load data, wind } \\
\text { power and solar PV data } \\
\text { for Germany) }\end{array}$} & & $10 \%$ & 1.0 & n.s. & \multirow{9}{*}{$\begin{array}{l}\text { No VRE curtailment or } \\
\text { related costs assumed }\end{array}$} \\
\hline & & Wind & $20 \%$ & 1.3 & n.s. & \\
\hline & & & $40 \%$ & 1.5 & n.s. & \\
\hline & & & $10 \%$ & 0.8 & & \\
\hline & & Solar PV & $20 \%$ & 1.3 & n.s. & \\
\hline & & & $40 \%$ & 2.0 & n.s. & \\
\hline & & \multirow{3}{*}{$\begin{array}{l}\text { Wind }(2 / 3) \text { and } \\
\text { solar PV }(1 / 3)\end{array}$} & $10 \%$ & 0.3 & n.s. & \\
\hline & & & $20 \%$ & 0.7 & n.s. & \\
\hline & & & $40 \%$ & 1.1 & n.s. & \\
\hline \multirow{3}{*}[14]{$^{1}$} & \multirow{3}{*}{$\begin{array}{l}\text { Meta-study (literature } \\
\text { sources used cover } \\
\text { several European } \\
\text { countries and several } \\
\text { regions of the USA) }\end{array}$} & \multirow{3}{*}{ Wind } & $10 \%$ & 0.5 & 0.8 & \multirow{3}{*}{$\begin{array}{l}\text { No VRE curtailment } \\
\text { costs included; based } \\
\text { on best-fit curve for } \\
\text { values of studies using } \\
\text { long-term models }\end{array}$} \\
\hline & & & $20 \%$ & 0.8 & 1.2 & \\
\hline & & & $40 \%$ & 1.3 & 2.2 & \\
\hline
\end{tabular}

${ }^{1}$ References [14,51] report marginal profile costs. Average costs are derived based on the marginal cost curves depicted in the studies and should be seen as approximate values; ${ }^{2}$ Costs in this study are provided in USD. These costs were converted to EUR by using a conversion rate of 1 EUR $=1.1 \mathrm{USD}$.

It should be noted that, particularly at high penetration rates of VRE technologies, profile costs differ considerably depending on how flexible the overall system is or is assumed to be in the future. Various studies show that the profile costs of VRE technologies can be reduced significantly through, among other things, consumer demand response (including temporal flexibility in charging electric vehicles), grid and storage capacity extensions, combining wind and solar PV with the use of dispatchable renewable energy technologies and also through system-friendly design, location or orientation/tilt of wind and solar PV plants [52,70-72]. Findings in studies indicating extremely high 
marginal profile costs for certain VRE shares (such as in [51] for solar PV shares exceeding about $15 \%$ and wind shares exceeding about $25 \%$ ) should therefore be interpreted with care if they do not assume that electricity demand will be able to adjust or that low-cost supply-side flexibility options can be achieved.

\subsection{External Costs}

This section introduces and discusses types of costs of electricity generation technologies that are not, or not fully, taken into account by the markets [73-75]. These so-called external costs are generally more difficult to identify and quantify than private costs because there are no markets on which their 'prices' can be observed and because, in many cases, complex environmental interactions occur before a burden (e.g., emission of an air pollutant) has an impact and leads to damage (e.g., a respiratory illness). Furthermore, many of the negative impacts are uncertain, locally removed to some degree from the actual source of the burden and/or occur with a significant time delay.

\subsubsection{Social Costs of Greenhouse Gas Emissions}

GHG emissions released by the combustion of fossil fuels contribute to global warming and ocean acidification and thus lead to damage and related costs. As will be discussed in the following, there are various difficulties in determining the Social Cost of Carbon (SCC), i.e., the monetized estimate of the change in expected social welfare resulting from a marginal change in $\mathrm{CO}_{2}$ emissions.

Integrated Assessment Models (IAMs) are typically used to derive estimates for the SCC. An IAM combines a global economic model with a model of the physical climate system and the carbon cycle. IAMs are based on estimates for the costs of a certain level of climate change [76]. These costs are used to calibrate the damage functions of the IAMs, which represent the costs of climate change for any level of global warming.

The range of estimates of the SCC found in the literature is large. There are various reasons why individual studies investigating the SCC tend to provide wide ranges and why these ranges vary considerably between different studies. A key factor responsible for variations in SCC estimates is the uncertainty related to future climate change, as well as its economic impacts and the potential of societies to adapt. Different methodological approaches also play a role in explaining the wide range of SCC estimates found in the literature. Methodological approaches differ, among other things, in the choice of a welfare function, the choice of a discount rate, the choice of whether or how to take into account potential aversion towards very high-consequence impacts of climate change and the choice of a time horizon [77-81].

Table 5 shows the SCC estimates provided by a US government-commissioned study. The Interagency Working Group on Social Cost of Carbon was tasked with deriving SCC estimates "to allow agencies to incorporate the social benefits of reducing carbon dioxide $\left(\mathrm{CO}_{2}\right)$ emissions into cost-benefit analyses of regulatory actions" [82]. While the authors acknowledge and discuss various general shortcomings of IAMs in their report, they nonetheless rely on three commonly used IAMs to derive a recommended range of SCC values. For the working group's SCC calculations, a range of socio-economic and emissions scenarios were used. The three values shown in columns 2, 3 and 4 of Table 5 are based on three different discount rates and are averages of the three IAMs used across the entire range of socio-economic and emissions scenarios. To represent the possibility of higher-than-expected economic impacts from climate change, the study also reports the value of the 95th percentile of the SCC estimates at a 3\% discount rate. This value is shown in column 5 of Table 5 . 
Table 5. Social cost of carbon estimates of $\mathrm{CO}_{2}$ emissions from the Interagency Working Group on Social Cost of Carbon.

\begin{tabular}{ccccc}
\hline & Average & 95th Percentile \\
\hline Discount rate & $5 \%$ & $3 \%$ & $2.5 \%$ & $3 \%$ \\
SCC value (in $€_{2015} /$ ton) & 11 & 37 & 58 & 109 \\
\hline
\end{tabular}

Source: [82]. Notes: The CPI Inflation Calculator from the US Department of Labor (http://www.bls.gov/data/ inflation_calculator.htm) was used to convert the $\mathrm{USD}_{2007}$ values provided in the original study to $\mathrm{USD}_{2015}$ values, before applying an exchange rate of $1.1 \mathrm{USD} / \mathrm{EUR}$ for conversion into EUR. The values refer to $\mathrm{CO}_{2}$ emissions in the year 2015.

Other studies, using mostly older versions of the three commonly used IAMs, tend to show lower values for the SCC. (A meta-analysis of 75 SCC studies released between 1982 and 2012 finds a mean value for the SCC of 7 USD per ton of $\mathrm{CO}_{2}$ for the year 2010 at a $3 \%$ discount rate [83]). In recent years, many authors have criticised the SCC values typically derived from IAMs and have provided a number of arguments supporting their belief that these values are systematically too low [80,84-87]. Many authors argue that there is a strong case for using lower discount rates than those used for central SCC estimates in most studies (typically around 3\%). As Table 5 indicates, the choice of discount rate has a considerable influence on the SCC estimate.

Furthermore, many authors argue that the IAMs typically used lead to SCC estimates that are too low for at least the following two additional reasons. Firstly, several types of climate change impacts are not, or not fully, included in the IAMs typically used to derive SCC. Among these impacts are the potential secondary social effects of climate change, such as damage resulting from climate change-induced armed conflicts, the negative impact of climate change on non-market goods such as biodiversity, and the potentially significant damage from increasing ocean acidification $[80,88,89]$. Secondly, the natural tendency to be risk-averse in the face of improbable but extremely severe consequences of future climate change is typically not captured in SCC estimates. This is especially important regarding the potentially catastrophic effects associated with tipping points [79,90-92].

Several authors have derived considerably higher SCC values than are typically reported from standard IAM runs by using lower discount rates and/or addressing the aforementioned shortcomings of IAMs. For example, van den Bergh and Botzen [80] conclude that a lower bound to the SCC of $€ 114$ (US\$125) per ton of $\mathrm{CO}_{2}$ can be derived when using a low discount rate and when taking low-probability/high-impact climate outcomes as well as risk aversion into account. The authors point out that this estimate still does not include various difficult to quantify climate change damage, so they argue that their lower bound of $€ 114$ per ton of $\mathrm{CO}_{2}$ should be regarded as a conservative estimate. Kopp et al. [90] have conducted a thorough sensitivity analysis of the SCC, using a modified version of the IAM DICE to derive scenarios with varying assumptions about the climate change damage specifications, calculating each scenario's SCC for different levels of risk aversion. Based on the different model specifications, the authors arrive at a broad range of SCC estimates. Assuming medium risk aversion, their median SCC values range between $€ 29$ and $€ 136$; assuming high risk aversion, this range increases to $€ 34-€ 626$. These results illustrate that different assumptions on how to formalise future climate change damage can lead to considerably higher SCC values compared to those obtained with standard damage functions, especially when combined with a highly risk-averse attitude. It is not possible to choose a "best" estimate from the broad range of SCC estimates found in the literature. Table 6, therefore, shows the lifecycle GHG emissions costs of various types of electricity generation using a broad range of SCC estimates from the literature. 
Table 6. Lifecycle GHG emissions costs of electricity generation technologies assuming a social cost of carbon of $€_{2015} 11$ (low), $€_{2015} 114$ (medium) and $€_{2015} 626$ (high) per ton of $\mathrm{CO}_{2}$-equivalent (in $€$-cent $2015 / \mathrm{kWh}$ ).

\begin{tabular}{cccc}
\hline Technology/Energy Source & Low & Medium & High \\
\hline Lignite & 1.0 & 10.2 & 56.2 \\
Coal & 0.9 & 9.0 & 49.6 \\
Natural gas & 0.4 & 4.5 & 24.8 \\
Coal CCS (post combustion) & 0.3 & 3.0 & 16.4 \\
Coal CCS (oxy-fuel) & 0.2 & 2.0 & 11.0 \\
Natural gas CCS & 0.1 & 1.5 & 8.3 \\
Biomass & $<0.1$ & 0.4 & 2.3 \\
Hydro & $<0.1$ & 0.1 & 0.4 \\
Solar PV & $<0.1$ & 0.3 & 1.7 \\
Wind (onshore) & $<0.1$ & 0.1 & 0.7 \\
Wind (offshore) & $<0.1$ & 0.1 & 0.6 \\
CSP & $<0.1$ & 0.2 & 1.3 \\
Geothermal & $<0.1$ & 0.5 & 2.5 \\
Ocean & $<0.1$ & 0.1 & 0.5 \\
Nuclear (LWR) & $<0.1$ & 0.1 & 0.8 \\
\hline
\end{tabular}

Sources: Calculations based on lifecycle GHG emissions data from [93] (fossil fuels); [94] (renewable energy sources) and [95] (nuclear power).

The lower value of $€ 11$ per ton of $\mathrm{CO}_{2}$ is the central value from the Interagency Working Group on Social Cost of Carbon [82] for emissions in the year 2015 at the relatively high discount rate of 5\%. For the median value, $€ 114$ per ton of $\mathrm{CO}_{2}$ is chosen, corresponding to the "lower bound" estimate by van den Bergh and Botzen [80]. The high value of $€ 626$ is based on the upper SCC value derived by Kopp et al. [90] when assuming high risk aversion. It should be noted that this range, although quite large, still fails to represent the full range of SCC estimates found in the literature.

\subsubsection{Impacts of Non-GHG Pollution Caused by Using Various Energy Sources}

The exploitation, transportation and conversion of fossil fuel energy sources and biomass invariably leads to the release of various forms of pollutants into the environment. These pollutants can affect air, water and soil quality and can have negative effects on human health, crops, building materials and the natural environment. Damage to human health resulting from air quality impairment is generally regarded as the most important consequence of such pollution [96] and is, therefore, the focus of this section. Power plants are prominent sources of pollutants such as nitrogen oxides, sulphur oxides, particulate matter, carbon monoxide, mercury, cadmium and lead [97].

Exposure to air pollution from power plants has been linked with various adverse human health effects. These include [98-104]:

- Neurological damage, especially to foetuses, newborns and children, leading e.g., to mental retardation, seizures or delayed development;

- Cardiovascular morbidity and mortality, e.g., strokes;

- Pulmonary morbidity and mortality, e.g., lung cancer;

- Respiratory diseases, especially in children, e.g., asthma.

Particulate matter $(\mathrm{PM})$, especially fine particulate matter $\left(\mathrm{PM}_{2.5}\right)$ consisting of particles with a diameter of 2.5 micrometres or less, has been identified by numerous studies to be the most significant pollutant from power plants to cause negative health effects $[105,106]$.

Unlike GHG emissions, which mix quickly within the earth's atmosphere, one unit of an air pollutant can result in different effects and, therefore, different costs depending on the location and characteristics of the source of the pollution. Representative estimates for the air pollution costs of power plants have been derived in the past for both the EU and the USA. Table 7 shows the lifecycle damage costs of air pollution per $\mathrm{kWh}$ for different kinds of newly-built power plants in 
Europe, as provided by the European research project "New Energy Externalities Development for Sustainability" (NEEDS) [107]. The table does not include estimates of damage due to climate change or negative effects on biodiversity (including land use), as these effects are discussed in separate sections of this article.

Table 7. Lifecycle air pollution costs of state-of-the-art (in around 2009) electricity generation technologies (2025 for CCS technologies) (in $€$-cent $2015 / \mathrm{kWh}$ ).

\begin{tabular}{ccccc}
\hline Technology/Energy Source & $\begin{array}{c}\text { Health } \\
\text { Impacts }\end{array}$ & $\begin{array}{c}\text { Crop Yield } \\
\text { Losses }\end{array}$ & $\begin{array}{c}\text { Material } \\
\text { Damage }\end{array}$ & Sum \\
\hline Nuclear power & 0.07 & 0.00 & 0.00 & $\mathbf{0 . 0 8}$ \\
Offshore wind & 0.07 & 0.00 & 0.00 & $\mathbf{0 . 0 7}$ \\
Ocean energy & 0.15 & 0.00 & 0.00 & $\mathbf{0 . 1 5}$ \\
CSP & 0.15 & 0.00 & 0.00 & $\mathbf{0 . 1 5}$ \\
Natural gas (CCGT) & 0.39 & 0.01 & 0.01 & $\mathbf{0 . 4 1}$ \\
Natural gas (CCGT, with post-combustion CCS) & 0.34 & 0.01 & 0.01 & $\mathbf{0 . 3 6}$ \\
Solar PV & 0.59 & 0.00 & 0.01 & $\mathbf{0 . 6 0}$ \\
Lignite & 0.90 & 0.02 & 0.01 & $\mathbf{0 . 9 4}$ \\
Hard coal & 1.31 & 0.02 & 0.02 & $\mathbf{1 . 3 6}$ \\
Hard coal (with post-combustion CCS) & 1.43 & 0.04 & 0.02 & $\mathbf{1 . 5 0}$ \\
Hard coal (with oxy-fuel CCS) & 1.04 & 0.02 & 0.02 & $\mathbf{1 . 0 8}$ \\
Biomass & 1.91 & 0.07 & 0.04 & $\mathbf{2 . 0 2}$ \\
\hline
\end{tabular}

Source: Data from [107].

It should be stressed that the power plants for which these pollution damage costs were calculated within the NEEDS project are generic power plants that were state-of-the-art around the year 2009. Currently operating power plants (in many cases decades old) typically cause much higher pollution damage, as they tend to use less advanced pollution control technologies and tend to be less efficient. The National Research Council study [96], for example, modelled the pollution damage for 406 coal-fired power plants operating in the United States in 2005 and found an average damage of $3.2 \$$-cent $2007 / \mathrm{kWh}\left(3.3 €\right.$-cent $\left.{ }_{2015} / \mathrm{kWh}\right)$ for the electricity from all plants and an average damage of $12 \$$-cent $2007 / \mathrm{kWh}(12.5 €$-cent $2015 / \mathrm{kWh})$ for the $5 \%$ of electricity from the most damaging coal-fired power plants. These figures include only the plants' emissions, not the full lifecycle emissions.

Epstein et al. [108] noted that the concentration-response function for $\mathrm{PM}_{2.5}$ derived by Pope et al. [101] and used by both the National Research Council study and the NEEDS study provided "a low estimate for increases in mortality risk with increases in $\mathrm{PM}_{2.5}$ exposure". Epstein et al. [108] point to a study by Schwartz et al. [109] that puts forward an estimate for $\mathrm{PM}_{2.5}$-related mortality considerably higher than that of Pope et al. [101]. According to Epstein et al. [108], using the concentration-response function of the study by Schwartz et al. [109] would lead to damage almost three times higher. Machol and Rizk [110] also find much higher external health costs than the National Research Council for coal power generation in the USA [96]. The differences in damage cost estimates between the studies highlight the considerable uncertainties in this field. The main uncertainties concern the negative health effects of pollutants, especially at relatively low levels, and the appropriate values to choose for a statistical life or a life year.

\subsubsection{Landscape and Noise Impacts}

Electricity generation plants may impact on people's welfare if they are affected by the visual appearance of these plants, by the landscape changes they cause or by the noise they emit. Wind power plants have been the most frequent subject of recent public discussion and scientific literature in terms of their impact on the landscape and the noise pollution they create.

One strand of literature on the landscape and noise externalities of wind power plants relies on the revealed preference method of examining the impact that new wind turbines (or the announcement of wind turbine development) have on the market value of nearby houses or properties. Results from 
these studies are mixed, with studies for North America generally finding no statistically significant relationship between wind turbine development and housing or property prices [111-114], but studies for several European countries finding evidence of a negative relationship [115-118]. These differences in the findings between European and US studies suggest that people in the USA are generally less disturbed by wind power plants located near their houses than people living in Europe. However, no literature was found that examines the reasons for these differences.

Another strand of literature relies on stated preference methods to infer how individuals value changes in their environment by establishing hypothetical markets through surveys. These studies [119-122] find that many people would be willing to pay to increase the distance of wind turbines to their homes or to the recreational areas they visit during holidays, up to a certain distance. Several of these studies find that younger people hold weaker preferences for reducing the disamenity impacts of wind turbines than older people. Ladenburg and Lutzeyer [120] note that an interesting question in this regard is whether this "age effect" is permanent or not. If it is permanent, i.e., if it is a generation effect, then the external landscape cost of wind power, if all things remain equal, can be expected to decline in the future.

Most of the literature sources examining visual and noise disamenities from wind power plants do not provide estimates, or enable estimates to be derived, for the related external costs per unit of generated electricity. Table 8 lists estimates for the external costs of landscape and noise impacts from five studies which provide this kind of information. As seen in Table 8, the estimates vary widely. However, all but one estimate is around $0.3 €$-cent $/ \mathrm{kWh}$ or lower, with the notable exception being a range of about $0.5-2 €$-cent derived from a study for The Netherlands [115]. The differences in the cost estimates are likely to be due mainly to differences in the studies' geographical scope as well as their methodological approaches. As mentioned above, in Europe people generally appear to feel more negative about wind power plants than in the US, and since the Netherlands is one of the most densely populated countries in Europe, more people tend to be affected by wind power plants compared to countries with a smaller population density. In terms of methodology, stated preference methods may tend to underestimate the full disamenity costs, as these methods may not capture all types of impacts (e.g., only visual but not noise impacts).

Table 8. Costs of landscape and noise impacts of onshore and offshore wind power plants at various locations in Europe and the USA according to several studies.

\begin{tabular}{|c|c|c|c|c|c|}
\hline $\begin{array}{l}\text { Type of } \\
\text { Wind } \\
\text { Power }\end{array}$ & Study & $\begin{array}{l}\text { Geographical } \\
\text { Scope }\end{array}$ & Method & $\begin{array}{l}\text { Costs of Landscape } \\
\text { and Noise Impacts } \\
\text { (in } € \text {-cent/kWh) }\end{array}$ & Comments \\
\hline \multirow[t]{3}{*}{ Onshore } & [115] & The Netherlands & Revealed preference & 0.90 & $\begin{array}{l}\text { Average; full range: } 0.5-2.0 \text {; } \\
\text { own assumptions made to } \\
\text { derive per kWh costs: home } \\
\text { buyers consider disamenity } \\
\text { over } 25 \text { years and the average } \\
\text { full load hours of onshore } \\
\text { wind turbines in the } \\
\text { Netherlands are } 2300 / a\end{array}$ \\
\hline & [123] & South Evia, Greece & Stated preference & 0.27 & - \\
\hline & [124] & Denmark & Revealed preference & 0.02 & $\begin{array}{l}\text { Investigated area sparsely } \\
\text { populated }\end{array}$ \\
\hline \multirow{3}{*}{ Offshore } & [119] & \multirow{2}{*}{ Delaware, USA } & \multirow{2}{*}{ Stated preference } & 0.28 & $\begin{array}{l}\text { Wind farm assumed to be } \\
3.6 \text { miles from the coast }\end{array}$ \\
\hline & & & & 0.07 & $\begin{array}{l}\text { Wind farm assumed to be } \\
6 \text { miles from the coast }\end{array}$ \\
\hline & [125] & $\begin{array}{l}\text { Lake Michigan } \\
\text { Area, USA }\end{array}$ & Stated preference & 0.08 & Mean value provided \\
\hline
\end{tabular}


Hydropower plants (especially those with dams) may also have relevant external landscape effects [126]. Several studies examine the impact of hydropower dams on nearby property prices [127-129] or use other revealed preference or stated preference methods to learn about people's preferences (e.g., concerning recreational usage) for free-flowing rivers and dammed river stretches [130-133]. However, results from these studies are not conclusive and they do not enable the related externalities from this technology to be quantified. A key challenge to establishing a general figure for the landscape externality of hydropower plants is that these plants' structures and impacts tend to differ significantly from one location to another.

The NEEDS study has chosen not to attempt to quantify damage derived from negative visual impacts for any of the technologies it analyses, noting that this damage is "affected by a considerable variability in time and space, which makes it impossible to adopt benefit transfer methods" [134]. At the same time, the authors of the NEEDS study state that there appears to be a "reasonable consensus" that this type of externality is not substantial compared to other types of externalities.

\subsubsection{Impacts on Ecosystems and Biodiversity (Non-Climate Change-Related)}

Electricity generation from various sources may lead to negative impacts on ecosystems and biodiversity. Impacts on ecosystems may take the form of damage to land, plant life, or animals. If, as a result of these impacts, the survival (locally or even globally) of a plant or animal species is threatened, biodiversity may be reduced.

The monetary impacts on ecosystems from human-induced climate change should ideally be included in the cost estimates for the GHG emissions discussed in Section 3.3.1. However, many of the IAMs used to estimate GHG emissions costs do not take ecosystem impacts fully into account $[79,135]$.

Table 9 shows estimates for the biodiversity costs of impacts caused by various forms of electricity generation as provided by the NEEDS study. Costs are shown separately for the impacts of airborne emissions and land-use changes and are assessed for newly-built, state-of-the-art power plants around the year 2009 (with the exception of CCS power plants, for which cost estimates are provided for the year 2025, as these kinds of plants were not in operation in 2009). The sum of both cost elements is low for most technologies when compared to the most relevant types of quantifiable external costs, i.e., GHG emissions costs (see Table 6) and health impact costs (see Table 7).

Table 9. Estimates for the costs of biodiversity impacts of state-of-the-art electricity generation technologies around the year 2009 (2025 for CCS technologies) (in $€$-cent $2015 / \mathrm{kWh}$ ).

\begin{tabular}{cccc}
\hline Technology/Energy Source & $\begin{array}{c}\text { Due to Airborne } \\
\text { Emissions }\end{array}$ & $\begin{array}{c}\text { Due to Land Use } \\
\text { Changes }\end{array}$ & Sum \\
\hline Nuclear power & $<0.01$ & 0.01 & $<0.1$ \\
Offshore wind & 0.00 & n.a. & n.a. \\
Ocean energy & 0.01 & 0.00 & $<0.1$ \\
CSP & 0.01 & n.a. & n.a. \\
Natural gas (CCGT) & 0.04 & 0.01 & $<0.1$ \\
Natural gas (CCGT, with post-combustion CCS) & 0.02 & 0.02 & $<0.1$ \\
Solar PV & 0.02 & n.a. & n.a. \\
Lignite & 0.09 & 0.01 & 0.1 \\
Hard coal & 0.11 & 0.06 & 0.2 \\
Hard coal (with post-combustion CCS) & 0.21 & 0.07 & 0.3 \\
Hard coal (with oxy-fuel CCS) & 0.09 & 0.07 & 0.2 \\
Biomass & 0.24 & 0.82 & 1.1 \\
\hline
\end{tabular}

Source: Data from [107].

It should be emphasised that due to a lack of data and a lack of a well-established methodology, these estimates of impacts on biodiversity are crude and imperfect. The complexity of nature's interdependencies and the contested question of whether animals and plants have an intrinsic value 
beyond their immediate value to mankind make such estimates a difficult exercise. Consequently, the figures cited here and shown in Table 9 should be treated with caution.

Furthermore, the cost estimates provided in Table 9 are not based on a full lifecycle assessment. Studies that attempt to systematically quantify and monetise the lifecycle effects on ecosystems, especially of fossil and nuclear fuel extraction, are not available.

Finally, biodiversity may also be affected directly by the physical structures of the power plants and their supporting equipment; this aspect is not included in the estimates provided in Table 9. This is most relevant for birds and bats, which are at risk of colliding with the physical structures. Collisions by birds and bats are most frequently discussed in the public domain and the literature in relation to wind power plants $[136,137]$. There are also indications of bird and bat deaths at solar thermal power plants and large-scale solar PV plants $[138,139]$, although it should be noted that the estimated avian mortality from both wind and solar power plants is reported to be significantly lower than from other human structures or activities, such as buildings and road vehicles [139].

Due to a lack of reliable and representative data, the specific threat that bird and bat fatalities at these and other types of power plants pose to biodiversity is difficult to gauge and clearly even more difficult to monetise. To the author's knowledge, to date there have been no studies that attempt to monetise the potential damage to biodiversity from bird or bat collisions.

\subsubsection{External Costs Associated with Radionuclide Emissions}

Radionuclide emissions can occur and be hazardous for human health during various stages of the nuclear power lifecycle. The likelihood and expected damage caused by large-scale nuclear accidents, as well as the question of how to monetise this damage, are highly contested issues in the literature and are the main reason for the wide divergence of external cost estimates of nuclear power. It should be noted that, in principle, large-scale accidents at other types of power plants may also lead to external costs. However, these non-internalised costs of non-nuclear accidents are reported to be negligible [140,141].

Severe accidents at nuclear power stations or other nuclear facilities, defined as accidents in which significant amounts of radioactive substances are released into the environment, have two important characteristics: the probability of such an accident occurring is very small and the potential damage is very high. The most common method for estimating the cost of a potential future accident is to calculate the summation of the probability of the occurrence of a scenario $\left(\mathrm{P}_{\mathrm{i}}\right)$ leading to an accident multiplied by the monetised damage from that accident $\left(\mathrm{C}_{\mathrm{i}}\right)$ over all plausible scenarios (i). This "expected damage" approach [142] can be represented by:

$$
\text { Expected value of damage }=\sum \mathrm{P}_{\mathrm{i}} \cdot \mathrm{C}_{\mathrm{i}}
$$

Studies that use this method typically conclude that the costs of a severe nuclear accident are small when expressed on a per kWh basis. However, using this method for determining the costs to society of a large-scale nuclear accident is frequently criticised in the literature. Critics point out that the public is generally very concerned about large-scale nuclear accidents and would be willing to pay much more than the expected value of damage to reduce or prevent the risks associated with a severe nuclear accident-even if the probability of such an accident is small. This discrepancy between expected damage calculations and public preferences might be due to a general aversion to risk of significant damage. Regarding severe nuclear accidents, people might not only be anxious about the negative impacts on their own health, but could also feel hostile about the drastic changes to society that could potentially ensue $[143,144]$.

However, not only is the question of how to interpret or weight the expected value of damage from a nuclear accident heavily debated in the literature, but the calculation of the expected value itself is also difficult and contentious. Both the probability $(P)$ and the cost $(C)$ of a nuclear accident scenario are difficult to determine. The probability of a severe nuclear accident is typically estimated 
by applying a probabilistic safety assessment (PSA). A PSA evaluates the potential causes of an accident, the probabilities of occurrence and the corresponding expected environmental releases [145]. Numerous PSA studies have been carried out in the past for different types of nuclear reactors and they typically conclude that for up-to-date reactor designs severe nuclear accidents are likely to happen no more than once every 100,000 to 10 million reactor years [142].

However, doubts are expressed by some authors about whether the PSA values are reliable estimates of the actual risk of severe accidents, even at newly-built reactors. It is argued that certain events, such as human misconduct, undiscovered manufacturing defects or complex, cross-linked system reactions can only be described in an incomplete manner by a PSA [144]. Furthermore, it is obviously extremely difficult to quantify—especially decades in advance-the risks to nuclear facilities posed by terrorism or warfare. Studies attempting to quantify the externalities of nuclear power typically note that potential safety risks posed by terrorism are not taken into account $[134,146]$.

Beyond the uncertainty about the probability of severe nuclear accidents, there are also significant uncertainties regarding the costs of such accidents if they occur $[142,147,148]$.

It can be concluded that due to high uncertainties and methodological challenges it is extremely difficult, if not impossible, to derive from the literature a meaningful range for the overall external costs of electricity generation from nuclear power. However, there is a general consensus in the literature that the external costs of nuclear power plants' normal operation (including damage caused by lifecycle GHG emissions and other pollutants as discussed above) are significantly lower than those for fossil fuel based electricity generation. Based on the NEEDS study [107] and Rabl and Rabl [146], a likely cost range for the external costs of normal operation may be 0.1-0.4 $€$-cent $/ \mathrm{kWh}$. External costs from nuclear accidents, however, are much more uncertain. Rabl and Rabl [146] derive a range of about $0.1-2.3 €$-cent $/ \mathrm{kWh}$ with a central value of about $0.4 €$-cent $/ \mathrm{kWh}$.

Due to the profound empirical and methodological challenges in quantifying the external costs of nuclear electricity generation, many authors suggest that any estimates of these kinds of costs should be treated with great caution-even more so than estimates of the external costs of other electricity generation technologies. Some authors suggest that ranking nuclear power and other power generation technologies should not be based on highly uncertain social cost estimates, but should rather rely on alternative tools, such as Multi Criteria Decision Analysis (MCDA) [134].

\subsubsection{Other Potential External Costs}

Other potential externalities of electricity generation are occasionally discussed in the literature. Among these additional potential externalities are:

- $\quad$ Supply disruptions $[134,149,150]$;

- Unintended funding of terrorism through the purchase of fossil fuels or uranium [151];

- $\quad$ Resettlement of people [152-155];

- Non-renewable resource extraction [156-158];

- Water withdrawal, consumption and contamination [159];

- Increased seismicity [160];

- Toxicity of materials used to build/manufacture plants [159];

- Type of ownership/preferences for self-subsistence [161,162].

Whether all these effects are externalities or not and, if they are, whether their respective costs are relevant or not is difficult to ascertain. To the author's knowledge, no quantitative and universal estimates of these potential externalities exist. 


\section{Synthesis: Comparing the Social Costs of Electricity Generation Technologies}

\subsection{Current Costs}

Based on the extensive literature review presented in Section 3, Tables 10 and 11 offer an overview of the social costs of electricity generation for various types of newly-built power plants in Europe and the USA respectively. As mentioned in Section 3.1.5, the analysis is limited to selected technologies for reasons of brevity.

The tables include available quantitative estimates for different types of external costs-albeit in many cases with considerable uncertainties. Indications are given in the tables about the role played by two additional types of external costs, which may be relevant but for which understanding is insufficient to derive meaningful quantitative estimates. The additional potential non-quantifiable external costs listed in Section 3.3.6 are not listed in Table 10 or Table 11 as, based on the literature, it is not possible to assess whether these are relevant or not. However, it should be mentioned that these potential additional external costs appear to be more relevant for nuclear power and fossil fuel technologies than for renewable energy technologies.

All the elements of system costs, as well as all external costs other than those associated with GHG emissions, vary significantly from one type of electricity system to another, and sometimes even within a particular electricity system. However, for reasons of simplification and because the information provided by the literature was deemed to be insufficient to confidently derive ranges for the external costs and the system costs, only point estimates of typical values are provided in the tables below. It should be kept in mind that, in specific circumstances, actual costs may deviate considerably from the values shown here. For plant-level costs, on the other hand, ranges as derived in Section 3.1.5 are included in the tables. There is also insufficient information in the literature to reliably quantify differences in system costs and external costs between Europe and the USA, so these are assumed to be identical in both regions, with the exception of the landscape and noise disamenity costs of onshore wind power. This is an oversimplification, as it is likely that due to (among other things) differences in geography, population density and solar and wind resources, there are non-negligible differences in the specific system costs and air pollution costs between Europe and the USA.

Using past annual transmission and distribution investments in Germany [163], it is estimated that average transmission costs of non-variable, dispatchable electricity generation are around $0.5 €$-cent $/ \mathrm{kWh}$. Median estimates for the additional costs for grid extension and reinforcement for VRE electricity generation are between 0.1 and $1.4 €$-cent $/ \mathrm{kWh}$, with the specific costs of solar $\mathrm{PV}$ tending to be a bit higher than for wind. Here we assume additional costs of $0.5 €$-cent $/ \mathrm{kWh}$ for electricity from onshore and offshore wind and of $1 €$-cent/kWh for solar PV power plants. This leads to total transmission costs of $1 €$-cent/ $\mathrm{kWh}$ for electricity generation from wind power plants (both onshore and offshore) and of $1.5 €$-cent $/ \mathrm{kWh}$ for electricity generation from solar PV power plants.

Balancing costs are also generally believed to be much more significant for electricity generation from VRE sources than for electricity generation from dispatchable sources. The few literature sources available which estimate the balancing costs of dispatchable power plants indicate that these costs for these plants are negligible. It is assumed in this paper for simplicity that these costs are zero for dispatchable power plants. Balancing costs for electricity generation from wind are given by various literature sources at about $0.3 €$-cent $/ \mathrm{kWh}$, with no clear correlation with wind penetration level. Few sources provide information on the balancing costs of electricity generation from solar PV plants, but the quantitative and qualitative information available suggests specific balancing costs are likely to be somewhat lower for solar PV than for wind. Specific balancing costs for electricity generation from solar PV power plants are, therefore, assumed to be $0.2 €$-cent $/ \mathrm{kWh}$ in this article. 
Table 10. Overview of the estimated specific social costs of electricity generation in Europe from several types of current newly-built power plants.

\begin{tabular}{|c|c|c|c|c|c|c|c|}
\hline \multirow{3}{*}{ Type of Cost } & \multicolumn{7}{|c|}{ Costs in $€$-cent $/ \mathrm{kWh}$} \\
\hline & \multicolumn{3}{|c|}{ Renewables } & \multirow{2}{*}{$\begin{array}{c}\text { Nuclear } \\
\text { (at a 3\% Discount } \\
\text { Rate) }\end{array}$} & \multirow{2}{*}{$\begin{array}{c}\text { Nuclear } \\
\text { (at a 6\% Discount } \\
\text { Rate) }\end{array}$} & \multicolumn{2}{|c|}{ Fossil Fuels } \\
\hline & $\begin{array}{c}\text { Onshore } \\
\text { Wind }\end{array}$ & $\begin{array}{l}\text { Offshore } \\
\text { Wind }\end{array}$ & $\begin{array}{c}\text { Solar PV } \\
\text { (Utility-Scale) }\end{array}$ & & & $\begin{array}{l}\text { Natural Gas } \\
\text { (CCGT) }\end{array}$ & Hard Coal \\
\hline \multicolumn{8}{|c|}{ Plant-level costs } \\
\hline Installation costs (central values) & 4.4 & 7.6 & 5.8 & 3.4 & 6.2 & 0.7 & 1.5 \\
\hline O\&M costs (central values) & 2.0 & 3.6 & 2.0 & 1.6 & 1.6 & 0.6 & 0.8 \\
\hline Fuel costs (central values) & 0.0 & 0.0 & 0.0 & 0.9 & 0.9 & 4.9 & 2.0 \\
\hline $\begin{array}{l}\text { Sum of plant-level costs (w/o } \mathrm{CO}_{2} \text { costs) } \\
\text { (central values; ranges in parenthesis) }\end{array}$ & $\begin{array}{c}6.4 \\
(2.5-9.7)\end{array}$ & $\begin{array}{c}\mathbf{1 1 . 2} \\
(7.5-14.9)\end{array}$ & $\begin{array}{c}7.8 \\
(5.3-10.1)\end{array}$ & $\begin{array}{c}5.8 \\
(4.8-6.9)\end{array}$ & $\begin{array}{c}8.6 \\
(6.8-10.1)\end{array}$ & $\begin{array}{c}6.2 \\
(5.9-6.7)\end{array}$ & $\begin{array}{c}4.3 \\
(3.3-4.8)\end{array}$ \\
\hline \multicolumn{8}{|c|}{ System costs } \\
\hline Grid costs & 1.0 & 1.0 & 1.0 & 0.5 & 0.5 & 0.5 & 0.5 \\
\hline Balancing costs & 0.3 & 0.3 & 0.2 & 0 & 0 & 0 & 0 \\
\hline $\begin{array}{c}\text { Profile costs } \\
\text { (additional costs for VRE plants for shares of } \\
\text { around or below 10\% for wind and solar PV each) }\end{array}$ & 1.0 & 1.0 & 1.0 & 0 & 0 & 0 & 0 \\
\hline Sum of system costs & 2.3 & 2.3 & 2.2 & 0.5 & 0.5 & 0.5 & 0.5 \\
\hline \multicolumn{8}{|c|}{ Quantifiable external costs } \\
\hline $\begin{array}{l}\text { GHG emissions costs } \\
\left.\text { (at } 114 € / \mathrm{tCO}_{2}\right)\end{array}$ & 0.1 & 0.1 & 0.3 & 0.1 & 0.1 & 4.5 & 9.0 \\
\hline $\begin{array}{l}\text { Air pollution costs } \\
\text { (state-of-the art plants) }\end{array}$ & $<0.1$ & $<0.1$ & 0.3 & $<0.1$ & $<0.1$ & 0.4 & 1.4 \\
\hline Landscape and noise disamenity costs & 0.5 & 0.2 & 0 & 0 & 0 & 0 & 0 \\
\hline Sum of quantifiable external costs & 0.6 & 0.3 & 0.6 & 0.1 & 0.1 & 4.9 & 10.4 \\
\hline $\begin{array}{l}\text { SUM OF ALL QUANTIFIABLE COSTS } \\
\text { (with central plant-level values; with plant-level } \\
\text { ranges in parenthesis) }\end{array}$ & $\begin{array}{c}9.3 \\
(5.4-12.6)\end{array}$ & $\begin{array}{c}13.8 \\
(10.1-17.5)\end{array}$ & $\begin{array}{c}10.6 \\
(8.1-12.9)\end{array}$ & $\begin{array}{c}6.4 \\
(5.4-7.5)\end{array}$ & $\begin{array}{c}9.2 \\
(7.4-10.7)\end{array}$ & $\begin{array}{c}\mathbf{1 1 . 6} \\
(11.3-12.1)\end{array}$ & $\begin{array}{c}15.2 \\
(14.2-15.7)\end{array}$ \\
\hline
\end{tabular}

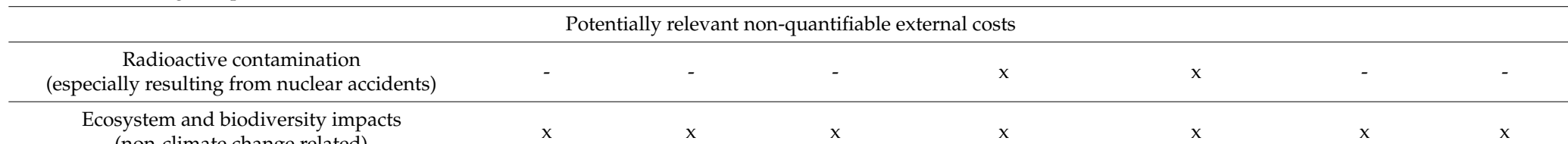

Sources: The original sources of the data presented in this table, as well as (where applicable) the assumptions made and approaches taken to derive representative values, can be found in the discussion of each cost type in Section 3 and in the text of this subsection (Section 4.1). 
Table 11. Overview of the estimated specific social costs of electricity generation in the USA from several types of current newly-built power plants.

\begin{tabular}{|c|c|c|c|c|c|c|c|}
\hline \multirow{3}{*}{ Type of Cost } & \multicolumn{7}{|c|}{ Costs in $€$-cent $/ \mathrm{kWh}$} \\
\hline & \multicolumn{3}{|c|}{ Renewables } & \multirow{2}{*}{$\begin{array}{c}\text { Nuclear } \\
\text { (at a 3\% Discount } \\
\text { Rate) }\end{array}$} & \multirow{2}{*}{$\begin{array}{c}\text { Nuclear } \\
\text { (at a } 6 \% \text { Discount } \\
\text { Rate) }\end{array}$} & \multicolumn{2}{|c|}{ Fossil Fuels } \\
\hline & $\begin{array}{c}\text { Onshore } \\
\text { Wind }\end{array}$ & $\begin{array}{l}\text { Offshore } \\
\text { Wind }\end{array}$ & $\begin{array}{c}\text { Solar PV } \\
\text { (Utility-Scale) }\end{array}$ & & & $\begin{array}{l}\text { Natural Gas } \\
\text { (CCGT) }\end{array}$ & Hard Coal \\
\hline \multicolumn{8}{|c|}{ Plant-level costs } \\
\hline Installation costs (central values) & 2.7 & 7.4 & 3.1 & 3.4 & 6.2 & 0.7 & 2.2 \\
\hline O\&M costs (central values) & 1.4 & 3.6 & 0.9 & 1.6 & 1.6 & 0.5 & 1 \\
\hline Fuel costs (central values) & 0 & 0 & 0 & 0.9 & 0.9 & 2.7 & 1.7 \\
\hline $\begin{array}{l}\text { Sum of plant-level costs ( } \mathrm{w} / \mathrm{o} \mathrm{CO}_{2} \text { costs) } \\
\text { (central values; ranges in parenthesis) }\end{array}$ & $\begin{array}{c}4.1 \\
(2.7-9.1)\end{array}$ & $\begin{array}{c}11.0 \\
(7.5-14.9)\end{array}$ & $\begin{array}{c}4.0 \\
(2.8-5.4)\end{array}$ & $\begin{array}{c}5.8 \\
(4.8-6.9)\end{array}$ & $\begin{array}{c}8.6 \\
(6.8-10.1)\end{array}$ & $\begin{array}{c}3.8 \\
(3.4-4.5)\end{array}$ & $\begin{array}{c}4.9 \\
(4.0-5.7)\end{array}$ \\
\hline \multicolumn{8}{|c|}{ System costs } \\
\hline Grid costs & 1.0 & 1.0 & 1.0 & 0.5 & 0.5 & 0.5 & 0.5 \\
\hline Balancing costs & 0.3 & 0.3 & 0.2 & 0 & 0 & 0 & 0 \\
\hline $\begin{array}{c}\text { Profile costs } \\
\text { (additional costs for VRE plants for shares of } \\
\text { around or below 10\% for wind and solar PV each) }\end{array}$ & 1.0 & 1.0 & 1.0 & 0 & 0 & 0 & 0 \\
\hline Sum of system costs & 2.3 & 2.3 & 2.2 & 0.5 & 0.5 & 0.5 & 0.5 \\
\hline \multicolumn{8}{|c|}{ External costs } \\
\hline $\begin{array}{l}\text { GHG emissions costs } \\
\text { (at } 114 € / \mathrm{tCO}_{2} \text { ) }\end{array}$ & 0.1 & 0.1 & 0.2 & 0.1 & 0.1 & 4.5 & 9.0 \\
\hline $\begin{array}{l}\text { Air pollution costs } \\
\text { (state-of-the art plants) }\end{array}$ & $<0.1$ & $<0.1$ & 0.2 & $<0.1$ & $<0.1$ & 0.4 & 1.4 \\
\hline Landscape and noise disamenity costs & 0.2 & 0.2 & 0 & 0 & 0 & 0 & 0 \\
\hline Sum of quantifiable external costs & 0.3 & 0.3 & 0.4 & 0.1 & 0.1 & 4.9 & 10.4 \\
\hline $\begin{array}{l}\text { SUM OF ALL QUANTIFIABLE COSTS } \\
\text { (with central plant-level values; } \\
\text { with plant-level ranges in parenthesis) }\end{array}$ & $\begin{array}{c}6.7 \\
(5.3-11.7)\end{array}$ & $\begin{array}{c}\mathbf{1 3 . 6} \\
(10.1-17.5)\end{array}$ & $\begin{array}{c}6.6 \\
(5.4-8.0)\end{array}$ & $\begin{array}{c}6.4 \\
(5.4-7.5)\end{array}$ & $\begin{array}{c}9.2 \\
(7.4-10.7)\end{array}$ & $\begin{array}{c}9.2 \\
(8.8-9.9)\end{array}$ & $\begin{array}{c}15.8 \\
(14.9-16.6)\end{array}$ \\
\hline \multicolumn{8}{|c|}{ Potentially relevant non-quantifiable external costs } \\
\hline $\begin{array}{c}\text { Radioactive contamination } \\
\text { (especially resulting from nuclear accidents) }\end{array}$ & - & - & - & $\mathrm{x}$ & $\mathrm{x}$ & - & - \\
\hline $\begin{array}{l}\text { Ecosystem and biodiversity impacts } \\
\text { (non-climate change related) }\end{array}$ & $x$ & $x$ & $x$ & $x$ & $\mathrm{x}$ & $\mathrm{x}$ & $\mathrm{x}$ \\
\hline
\end{tabular}

Sources: The original sources of the data presented in this table, as well as (where applicable) the assumptions made and approaches taken to derive representative values, can be found in the discussion of each cost type in Section 3 and in the text of this subsection (Section 4.1) 
Literature estimates on specific profile costs vary considerably and generally increase as the penetration level of VRE generation grows. Currently, in most electricity systems in Europe and the USA, the respective shares of wind power generation are below $10 \%$ and of solar PV generation below $5 \%$, so specific marginal profile costs are currently relatively low and are assumed in this article to be $1 €$-cent/kWh for both wind and solar PV. No reliable information was found on the difference between profile costs for electricity generation from onshore wind and offshore wind, so no differentiation between the two could be made. However, it is likely that the generally higher capacity factors and steadier generation of offshore wind turbines mean that these are associated with lower profile costs than onshore turbines.

While electricity systems with only dispatchable power plants also require some balancing and excess generating capacities, the associated costs for dispatchable power plants are relatively small and are assumed to be zero. It should be stressed that this is only true under the assumption that the electricity system contains a cost-optimal mix of thermal baseload power plants (fossil fuel and/or nuclear power). This assumption allows for no system costs to be allocated to baseload power plants but it also means that if there were plans to significantly increase the penetration of nuclear power, for example, the marginal costs of additional plants would eventually be higher than indicated in this article.

It should be stressed that in the following tables the marginal profile costs are given (as opposed to the average profile costs), as the aim is to compare the cost of additional electricity generation from any one technology. This also means that in Tables 10-12 and even more so in Tables 13-15, the average costs of wind and solar PV electricity generation are lower than the marginal costs shown.

In terms of the costs of GHG emissions, the medium value for the SCC as derived in Section 3.3.1 is used. As there is considerable disagreement about the "appropriate" SCC value and as this type of external cost significantly influences the social costs of fossil fuel technologies, Table 12 provides a sensitivity analysis of the quantifiable social costs using the lower and higher SCC values derived in Section 3.3.1. For reasons of brevity, this sensitivity analysis is only shown for Europe. For air pollution costs, the values from the NEEDS study as presented in Section 3.3.2 are used. As the specific (life-cycle) GHG and air pollution emissions of solar PV plants are based on European conditions and typical solar PV capacity factors in the US are roughly twice those in Europe, the specific GHG and air pollution costs of solar PV plants in the USA are assumed to be half of those in Europe.

As a third quantifiable external type of cost, the landscape and noise disamenity costs are also estimated based on the literature discussed in Section 3.3.3. These costs are assumed to be relevant only for onshore and offshore wind power and not for any other type of power plant. For onshore wind, disamenity costs of $0.5 €$-cent $/ \mathrm{kWh}$ are assumed for Europe. This corresponds to the lower value derived from the study for the Netherlands [115], because other studies (such as [123]) arrive at lower costs and the population density of the Netherlands is much higher than the European average. For the USA, disamenity costs for onshore wind appear to be lower and are assumed to be $0.2 €$-cent $/ \mathrm{kWh}$ in this article. For offshore wind, disamenity costs for both Europe and the USA are assumed to be $0.2 €$-cent/kWh.

Due to the extremely wide range of estimates of the external costs of potential nuclear accidents, this type of externality is classified in this article as a "non-quantifiable" external cost. While cost estimates of the impact on the ecosystem and on biodiversity do exist, these estimates do not appear to be comprehensive and, due to a lack of similar analysis in the literature, it is unclear how reliable they are. Therefore, the costs of ecosystem and biodiversity impacts are also classified as "non-quantifiable". 
Table 12. Sensitivity to the assumed social cost of carbon value of the estimated specific social costs of electricity generation in Europe from several types of current newly-built power plants.

\begin{tabular}{|c|c|c|c|c|c|c|c|c|}
\hline \multirow{3}{*}{ Type of Cost } & & \multicolumn{7}{|c|}{ Costs in $€$-cent $/ \mathbf{k W h}$} \\
\hline & & \multicolumn{3}{|c|}{ Renewables } & \multirow{2}{*}{$\begin{array}{c}\text { Nuclear } \\
\text { (at a 3\% Discount Rate) }\end{array}$} & \multirow{2}{*}{$\begin{array}{c}\text { Nuclear } \\
\text { (at a } 6 \% \text { Discount Rate) }\end{array}$} & \multicolumn{2}{|c|}{ Fossil Fuels } \\
\hline & & Onshore Wind & Offshore Wind & Solar PV (Utility-Scale) & & & Natural Gas (CCGT) & Hard Coal \\
\hline \multirow{3}{*}{ GHG emissions costs } & $\begin{array}{c}\text { Low } \\
\left(11 € / \mathrm{tCO}_{2}\right) \\
\end{array}$ & $<0.1$ & $<0.1$ & $<0.1$ & $<0.1$ & $<0.1$ & 0.4 & 0.9 \\
\hline & $\begin{array}{c}\text { Medium } \\
\left(114 € / \mathrm{tCO}_{2}\right)\end{array}$ & 0.1 & 0.1 & 0.3 & 0.1 & 0.1 & 4.5 & 9.0 \\
\hline & $\begin{array}{c}\text { High } \\
\left(626 € / \mathrm{tCO}_{2}\right)\end{array}$ & 0.7 & 0.6 & 1.7 & 0.8 & 0.8 & 24.8 & 49.6 \\
\hline All other quantifiable costs (with centra & plant-level values) & 9.2 & 13.7 & 10.3 & 6.3 & 9.1 & 7.1 & 6.2 \\
\hline \multirow{3}{*}{$\begin{array}{l}\text { SUM OF ALL QUANTIFIABLE COSTS } \\
\text { (with central plant-level values) }\end{array}$} & $\begin{array}{c}\text { Low } \mathrm{CO}_{2} \text { costs } \\
\left(11 € / \mathrm{tCO}_{2}\right)\end{array}$ & 9.2 & 13.7 & 10.3 & 6.3 & 9.1 & 7.5 & 7.1 \\
\hline & $\begin{array}{c}\text { Medium } \mathrm{CO}_{2} \text { costs } \\
\left(114 € / \mathrm{tCO}_{2}\right)\end{array}$ & 9.3 & 13.8 & 10.6 & 6.4 & 9.2 & 11.6 & 15.2 \\
\hline & $\begin{array}{c}\mathrm{High} \mathrm{CO}_{2} \text { costs } \\
\left(626 € / \mathrm{t} \mathrm{CO}_{2}\right)\end{array}$ & 9.9 & 14.3 & 12.0 & 7.1 & 9.9 & 31.9 & 55.8 \\
\hline
\end{tabular}

Sources: The original sources of the data presented in this table, as well as (where applicable) the assumptions made and approaches taken to derive representative values, can be found in the discussion of each cost type in Section 3 and in the text of this subsection (Section 4.1)

Table 13. Overview of the estimated specific social costs of electricity generation in Europe from several types of power plants assumed to start operating in 2040

\begin{tabular}{|c|c|c|c|c|c|c|c|}
\hline \multirow{3}{*}{ Type of Cost } & \multicolumn{7}{|c|}{ Costs in $€$-cent $/ \mathrm{kWh}$} \\
\hline & \multicolumn{3}{|c|}{ Renewables } & \multirow{2}{*}{$\begin{array}{c}\text { Nuclear } \\
\text { (at a 3\% Discount Rate) }\end{array}$} & \multirow{2}{*}{$\begin{array}{c}\text { Nuclear } \\
\text { (at a } 6 \% \text { Discount Rate) }\end{array}$} & \multicolumn{2}{|c|}{ Fossil Fuels } \\
\hline & $\begin{array}{c}\text { Onshore } \\
\text { Wind }\end{array}$ & $\begin{array}{l}\text { Offshore } \\
\text { Wind }\end{array}$ & $\begin{array}{c}\text { Solar PV } \\
\text { (Utility-Scale) }\end{array}$ & & & $\begin{array}{l}\text { Natural Gas } \\
\text { (CCGT) }\end{array}$ & Hard Coal \\
\hline $\begin{array}{l}\text { Sum of plant-level costs ( } \mathrm{w} / \mathrm{o} \mathrm{CO}_{2} \text { costs) } \\
\text { (central values; ranges in parenthesis) }\end{array}$ & $\begin{array}{c}5.5 \\
(2.3-8.3)\end{array}$ & $\begin{array}{c}7.6 \\
(4.7-11.1) \\
\end{array}$ & $\begin{array}{c}4.6 \\
(3.0-6.2)\end{array}$ & $\begin{array}{c}5.8 \\
(4.8-6.9)\end{array}$ & $\begin{array}{c}8.6 \\
(6.8-10.1)\end{array}$ & $\begin{array}{c}6.2 \\
(5.9-6.7)\end{array}$ & $\begin{array}{c}4.3 \\
(3.3-4.8)\end{array}$ \\
\hline Grid costs & 1.0 & 1.0 & 1.0 & 0.5 & 0.5 & 0.5 & 0.5 \\
\hline Balancing costs & 0.3 & 0.3 & 0.2 & 0 & 0 & 0 & 0 \\
\hline $\begin{array}{l}\text { Profile costs (additional costs for VRE plants for shares of around 35\% } \\
\text { for wind and 15\% for solar PV) }\end{array}$ & 2.5 & 2.5 & 2.5 & 0 & 0 & 0 & 0 \\
\hline Sum of system costs & 3.8 & 3.8 & 3.7 & 0.5 & 0.5 & 0.5 & 0.5 \\
\hline Sum of quantifiable external costs & 0.5 & 0.2 & 0.1 & 0.1 & 0.1 & 4.9 & 10.4 \\
\hline $\begin{array}{l}\text { SUM OF ALL QUANTIFIABLE COSTS } \\
\text { (with central plant-level values; with plant-level ranges in parenthesis) }\end{array}$ & $\begin{array}{c}9.8 \\
(6.6-12.6)\end{array}$ & $\begin{array}{c}11.6 \\
(8.5-15.1)\end{array}$ & $\begin{array}{c}8.4 \\
(6.8-10.0)\end{array}$ & $\begin{array}{c}6.4 \\
(5.4-7.5)\end{array}$ & $\begin{array}{c}9.2 \\
(7.4-10.7)\end{array}$ & $\begin{array}{c}11.6 \\
(11.3-12.1)\end{array}$ & $\begin{array}{c}15.2 \\
(14.2-15.7)\end{array}$ \\
\hline
\end{tabular}

Sources: The original sources of the data presented in this table, as well as (where applicable) the assumptions made and approaches taken to derive representative values, can be found in the discussion of each cost type in Section 3 and in the text of this subsection (Section 4.2). 
Table 14. Overview of the estimated specific social costs of electricity generation in the USA from several types of power plants assumed to start operating in 2040.

\begin{tabular}{|c|c|c|c|c|c|c|c|}
\hline \multirow{3}{*}{ Type of Cost } & \multicolumn{7}{|c|}{ Costs in $€$-cent $/ \mathbf{k W h}$} \\
\hline & \multicolumn{3}{|c|}{ Renewables } & \multirow{2}{*}{$\begin{array}{c}\text { Nuclear } \\
\text { (at a 3\% Discount Rate) } \\
\end{array}$} & \multirow{2}{*}{$\begin{array}{c}\text { Nuclear } \\
\text { (at a } 6 \% \text { Discount Rate) }\end{array}$} & \multicolumn{2}{|c|}{$\begin{array}{l}\text { Fossil Fuels } \\
\end{array}$} \\
\hline & Onshore Wind & Offshore Wind & Solar PV (Utility-Scale) & & & Natural Gas (CCGT) & Hard Coal \\
\hline $\begin{array}{l}\text { Sum of plant-level costs }\left(\mathrm{w} / \mathrm{o} \mathrm{CO}_{2} \text { costs) }\right. \\
\text { (central values; ranges in parenthesis) }\end{array}$ & $\begin{array}{c}3.7 \\
(2.3-7.2)\end{array}$ & $\begin{array}{c}7.6 \\
(4.7-11.1)\end{array}$ & $\begin{array}{c}2.7 \\
(1.6-3.4)\end{array}$ & $\begin{array}{c}5.8 \\
(4.8-6.9)\end{array}$ & $\begin{array}{c}8.6 \\
(6.8-10.1)\end{array}$ & $\begin{array}{c}3.8 \\
(3.4-4.5)\end{array}$ & $\begin{array}{c}4.9 \\
(4.0-5.7)\end{array}$ \\
\hline Grid costs & 1.0 & 1.0 & 1.0 & 0.5 & 0.5 & 0.5 & 0.5 \\
\hline Balancing costs & 0.3 & 0.3 & 0.2 & 0 & 0 & 0 & 0 \\
\hline $\begin{array}{l}\text { Profile costs } \\
\text { (additional costs for VRE plants for shares of } \\
\text { around } 35 \% \text { for wind and } 15 \% \text { for solar PV) }\end{array}$ & 2.5 & 2.5 & 2.5 & 0 & 0 & 0 & 0 \\
\hline Sum of system costs & 3.8 & 3.8 & 3.7 & 0.5 & 0.5 & 0.5 & 0.5 \\
\hline Sum of quantifiable external costs & 0.3 & 0.2 & 0.1 & 0.1 & 0.1 & 4.9 & 10.4 \\
\hline $\begin{array}{l}\text { SUM OF ALL QUANTIFIABLE COSTS } \\
\text { (with central plant-level values; } \\
\text { with plant-level ranges in parenthesis) }\end{array}$ & $\begin{array}{c}7.8 \\
(6.4-11.3)\end{array}$ & $\begin{array}{c}11.6 \\
(8.7-15.1)\end{array}$ & $\begin{array}{c}6.5 \\
(5.4-7.2)\end{array}$ & $\begin{array}{c}6.4 \\
(5.4-7.5)\end{array}$ & $\begin{array}{c}9.2 \\
(7.4-10.7)\end{array}$ & $\begin{array}{c}9.2 \\
(8.8-9.9)\end{array}$ & $\begin{array}{c}15.8 \\
(14.9-16.6)\end{array}$ \\
\hline
\end{tabular}

Sources: The original sources of the data presented in this table, as well as (where applicable) the assumptions made and approaches taken to derive representative values, can be found in the discussion of each cost type in Section 3 and in the text of this subsection (Section 4.2).

Table 15. Overview of the estimated specific social costs (central values) of electricity generation in Europe from several types of power plants built in 2040 depending on how profile costs are allocated.

\begin{tabular}{|c|c|c|c|c|c|c|c|c|}
\hline & \multirow{3}{*}{ Type of Cost } & \multicolumn{7}{|c|}{ Costs in $\epsilon$-cent $/ \mathrm{kWh}$} \\
\hline & & \multicolumn{3}{|c|}{ Renewables } & \multirow{2}{*}{$\begin{array}{c}\text { Nuclear } \\
\text { (at a 3\% Discount Rate) }\end{array}$} & \multirow{2}{*}{$\begin{array}{c}\text { Nuclear } \\
\text { (at a 6\% Discount Rate) }\end{array}$} & \multicolumn{2}{|c|}{ Fossil Fuels } \\
\hline & & Onshore Wind & Offshore Wind & Solar PV (Utility-Scale) & & & Natural Gas (CCGT) & Hard Coal \\
\hline \multirow{2}{*}{$\begin{array}{l}\text { Sum of plant-level } \\
\text { costs... }\end{array}$} & $\begin{array}{l}\text {...when all of the profile costs are } \\
\text { allocated to VRE generation }\end{array}$ & 5.5 & 7.6 & 4.6 & 5.8 & 8.6 & 6.2 & 4.3 \\
\hline & $\begin{array}{l}\text {...when parts of the profile costs are } \\
\text { allocated to baseload generation }\end{array}$ & 5.5 & 7.6 & 4.6 & 8.9 & 13.6 & 6.9 & 5.7 \\
\hline \multirow{2}{*}{$\begin{array}{l}\text { Sum of system } \\
\text { costs... }\end{array}$} & $\begin{array}{l}\text {...when all of the profile costs are } \\
\text { allocated to VRE generation }\end{array}$ & 3.8 & 3.8 & 3.7 & 0.5 & 0.5 & 0.5 & 0.5 \\
\hline & $\begin{array}{l}\text {...when parts of the profile costs are } \\
\text { allocated to baseload generation }\end{array}$ & 2.8 & 2.8 & 1.2 & 0.5 & 0.5 & 0.5 & 0.5 \\
\hline \multicolumn{2}{|c|}{ Sum of quantifiable external costs } & 0.5 & 0.2 & 0.1 & 0.1 & 0.1 & 4.9 & 10.4 \\
\hline \multirow{2}{*}{$\begin{array}{l}\text { SUM OF ALL } \\
\text { QUANTIFIABLE } \\
\text { COSTS... }\end{array}$} & $\begin{array}{l}\text {...when all of the profile costs are } \\
\text { allocated to VRE generation }\end{array}$ & 9.8 & 11.6 & 8.4 & 6.4 & 9.2 & 11.6 & 15.2 \\
\hline & $\begin{array}{l}\text {...when parts of the profile costs are } \\
\text { allocated to baseload generation }\end{array}$ & 8.8 & 10.6 & 5.9 & 9.5 & 14.2 & 12.3 & 16.6 \\
\hline
\end{tabular}

Sources: The original sources of the data presented in this table, as well as (where applicable) the assumptions made and approaches taken to derive representative values, can be found in the discussion of each cost type in Section 3 and in the text of this subsection (Section 4.2). 
As Table 10 shows, when only considering the quantifiable social costs and neglecting differences in investment risks, nuclear power is currently the cheapest option for electricity generation in Europe, although onshore wind power at good sites can have comparable costs. Assuming, on the other hand, that the greater investment risks for nuclear power plants are adequately captured by a higher discount rate of $6 \%$, both nuclear power and typical onshore wind power plants exhibit virtually the same quantifiable social central value cost of just over $9 €$-cent $/ \mathrm{kWh}$. In the USA, nuclear power (when neglecting higher investment risks), utility-scale solar PV and onshore wind power plants currently exhibit the lowest quantifiable social costs, with their central values all between 6 and $7 €$-cent/kWh. Regarding the values for nuclear power, it should be stressed that these costs do not include the risks associated with accidents at—or attacks on—nuclear power facilities.

\subsection{Expected Costs in 2040}

Tables 13 and 14 show the estimated social costs of electricity generation in Europe and the USA for plants to be built in 2040. For these tables, it is assumed that the plant-level costs of renewable energy technologies will continue to decline in the coming decades due to further reductions in investment and O\&M costs. Specifically, capital costs and O\&M costs in 2040 for onshore wind, offshore wind and solar PV are taken from Teske et al. [6], which use an experience curve approach to estimate future costs. The capacity factors are assumed to remain constant, with the exception of solar PV in the USA. For this technology the central estimate for capacity factor was assumed to decline from the current value of $25.8 \%$ to $23 \%$, given that it is likely that future deployment at higher penetration rates will no longer be able to focus so strongly on the best solar irradiation sites [43]. The costs of electricity generation from fossil fuel technologies remain constant, under the assumption that any technological learning that may still take place between today and 2040 will be compensated for by rising fuel prices. The costs of power generation from nuclear power also remain constant, under the assumption that the nuclear industry will be successful in avoiding the type of cost increases that have been observed in past decades, especially in the USA and Europe [164-166].

In 2040, the penetration rate of VRE technologies in Europe and the USA is likely to be much higher than today, perhaps around 50\% [30,167]. Therefore, for the marginal specific profile costs of VRE electricity generation in 2040, the cost estimates in the literature for higher VRE shares are relevant. It is assumed that solar PV will have a share of about $15 \%$ and will cause specific marginal profile costs of $2.5 €$-cent, while the same marginal costs are assumed to accrue for wind power for an anticipated share of about $35 \%$. These marginal profile cost estimates for wind and solar PV are somewhat lower than those found by Ueckerdt et al. [51] for similar VRE shares. Lower values were chosen because the other two studies cited in Section 3.2.3 arrive at lower marginal and/or average profile costs than Ueckerdt et al. [51], even at penetration rates at which VRE overproduction costs (which are not included in the other two studies) do not yet play a role according to Ueckerdt et al. [51].

For the sake of simplicity, all other system costs are held constant at their current values, although specific balancing costs, for example, may decline over time as a result of technological progress. For the most part, the external costs are also assumed to remain constant, although the expected further improvements in the lifecycle GHG and air pollution emissions for wind and solar PV plants are taken into account. Detailed information about the specific assumptions can be found in the Supplementary Materials. For reasons of brevity, the non-quantifiable external costs are not listed again in Tables 13 and 14.

As it is a matter of debate whether or not it is appropriate to allocate the full profile costs of additional VRE power generation to the new VRE power plants, Table 15 takes another approach to allocating these costs in a technology specific comparison for 2040. This alternative approach assumes that the additional costs caused by new VRE power generation in the residual system are allocated to the dispatchable power plants, as this is where these costs actually manifest themselves. Specifically, it is assumed that the capacity factors of the dispatchable power plants decrease from $85 \%$ (current estimate) to $50 \%$ in 2040 . This leads to considerably higher plant-level costs of the dispatchable power 
plants. Taking such an approach, the profile costs of VRE electricity generation consist only of the overproduction costs, as the additional costs accruing in the residual system are now reflected in the higher costs of dispatchable electricity generation. Following Ueckerdt et al. [51], the overproduction costs are assumed to be $1.5 €$-cent $/ \mathrm{kWh}$ for wind for a share of $35 \%$ and negligible for solar PV for a share of $15 \%$.

As Table 13 suggests, in Europe and the USA further plant-level cost reductions for solar PV and wind power by 2040 are expected to be partly compensated (solar PV, offshore wind) or even overcompensated (onshore wind) by higher system costs, if profile costs are fully allocated to VRE power generation. Therefore, in Europe, nuclear power may still be the least expensive option in terms of quantifiable social costs, when not accounting for its higher investment risks. If these are taken into consideration by using a higher discount rate of $6 \%$, the central cost estimate is lowest for solar PV ( $8.4 €$-cent $/ \mathrm{kWh})$, followed by nuclear power $(9.2 €$-cent $/ \mathrm{kWh}$ ) and onshore wind $(9.8 €$-cent $/ \mathrm{kWh})$. When the increase in the specific costs of the residual system due to additional VRE power penetration is not allocated to wind and solar PV, but to the dispatchable power plants that will suffer from lower capacity factors, solar PV and onshore wind can be expected to be the cheapest options in 2040, followed by nuclear power and offshore wind.

In the USA, by 2040, when fully allocating the profile costs to VRE power generation and ignoring differences in investment risks, both nuclear power and solar PV can be expected to have virtually the same quantifiable social costs, followed by onshore wind. Solar PV and onshore wind are clearly expected to be the options with the lowest quantifiable social costs if the additional risks of nuclear power investments are taken into account (by using a $6 \%$ discount rate) and/or if parts of the profile costs are allocated to the dispatchable plants.

In both Europe and the USA, electricity from offshore wind, solar thermal power plants and coal CCS plants (the latter two are not shown in the tables) is expected to remain more expensive than electricity from other low-carbon sources, namely onshore wind, solar PV and nuclear power [21,168].

\section{Conclusions and Further Research Needs}

The literature review in Section 3 and the synthesis in Section 4 emphasise that not only plant-level costs, but also system costs and external costs are relevant when comparing the social costs of electricity generation. According to the cost estimates used here, system costs may (in the future) constitute more than $50 \%$ of the total social costs of VRE power generation at relatively high VRE market penetration (and assuming that the profile costs of additional VRE power generation are allocated entirely to VRE power generation itself). The quantifiable external costs, on the other hand, are most relevant for fossil fuel power generation and may account for about $25 \%$ of the total quantifiable social costs of coal power at low SCC assumptions and for about $90 \%$ at high SCC assumptions. These findings emphasise that all three cost categories (plant-level costs, system costs and external costs) should be taken into account when attempting to advise society and policymakers on a least-cost approach to future electricity supply.

Table 16 underscores this conclusion by providing for each identified sub-category of costs its relevance in social cost comparisons of different electricity generation technologies. "Low" relevance means that the maximum differences in a certain category of costs between individual technologies are less than $0.5 €$-cent $/ \mathrm{kWh}$; "medium" relevance means that these differences are between 0.5 and less than $2 €$-cent/kWh; and "high" relevance means that they are $2 €$-cent/kWh or higher. Based on the extensive literature review, Table 16 also provides an assessment by the author of the current scientific understanding regarding each cost category. 
Table 16. Assessment of the relevance of individual cost categories for social cost comparisons for electricity generation technologies and of the scientific understanding of each category.

\begin{tabular}{ccc}
\hline Cost Category & Relevance for Comparing Costs & Scientific Understanding \\
\hline & Plant-level costs & \\
\hline Capital costs & High & High \\
Fuel costs & High & Moderate to high \\
High \\
Market costs of GHG emissions & High & Moderate to high \\
Non-fuel O\&M costs & High & \\
\hline \multicolumn{4}{c}{ System costs } & Moderate \\
Grid costs & Low to medium & Moderate to high \\
Balancing costs & Low & Moderate \\
Profile costs & Medium to high & \\
\hline & External costs & Low \\
& Medium to high & Low to medium \\
\hline Social costs of GHG emissions & Medium & Low to medium \\
Impacts of non-GHG pollution & Low to medium & Low \\
Visual impacts and impacts of noise & Unclear & Low \\
Impacts on ecosystems \& biodiversity (non-climate) & Unclear & Very low \\
Costs associated with radionuclide emissions & Unclear & \\
Other potential external costs &
\end{tabular}

This literature review of the social costs of electricity generation thus illustrates what types of costs should ideally be included in any analysis that aims to inform policymakers on least-cost developments of the electricity system. Any such advice should also clearly communicate the considerable uncertainties surrounding the social costs of electricity generation regarding, among other things:

- The costs to assign to specific $\mathrm{CO}_{2}$ emissions;

- The costs to assign to specific air pollution emissions;

- The types of costs that are highly location-specific, such as disamenity costs;

- The profile costs of VRE power generation in future electricity systems with very high VRE shares;

- The relevance of several potential externalities (including the costs of potential nuclear accidents) for which no widely accepted methods of quantification exist.

Notwithstanding these uncertainties, the analysis in this paper suggests that even at low SCC estimates, the "new" renewable technologies of onshore wind and (in some regions of the world) solar PV can already compete with fossil fuel technologies in terms of the total social costs. Furthermore, in the USA, onshore wind and solar PV exhibit not only lower quantifiable social costs than fossil fuel technologies, but also similar costs to nuclear power as a competing low-carbon technology, even if the higher investment risks of nuclear power and the risks associated with radionuclide release are ignored. In Europe, this is true for onshore wind plants at favourable sites. In the longer term, the relative costs of low-carbon electricity generating technologies will largely depend on the system costs caused by additional VRE power generation and the allocation of these costs.

Future research can help to improve our understanding of the total social costs of electricity generation. This is true in terms of the landscape and noise disamenity costs of wind power and possibly other types of power plants. Future research could, for example, attempt to shed light on the apparent differences in these costs from one country to another, how these costs can be expected to evolve in the future and what measures can be taken to minimise these costs. Furthermore, as the penetration of VRE power generation is expected to increase considerably in the coming decades, the question of how steeply system costs will rise and how to minimise these costs is of growing importance. For example, studies could investigate the optimal mix of residual power plants, the optimal design and deployment of VRE power plants or the potential for better demand response, possibly supported by the stronger integration of the power, heat and fuel markets. 
Finally, the limitations of a technology-specific comparison of electricity generation costs, as attempted in this study, should be emphasised.

Firstly, as discussed above, the literature review has demonstrated that considerable uncertainties remain in the quantification of the social costs of electricity generation. This uncertainty is especially high in relation to externalities for which quantification (in the form of a useful range of values) remains elusive. Among these externalities are potential accidents or attacks on nuclear power facilities. The author of this article agrees with the perspective that, due to the potential of extremely high social impacts of such incidences, deriving a specific cost for nuclear accidents is futile and, instead, societies should agree on whether or to what extent they wish to use this technology.

Secondly, and more generally, the electricity system is a highly-interconnected system, in which different power plants and electricity consumers interact with one another. The costs of generating and supplying electricity from any one specific power plant depend on the characteristics of the existing electricity system, such as the mix of power plants, the quality of the electricity grid and the nature and flexibility of electricity demand. In the overview of costs provided in Section 4 and the underlying literature sources, implicit assumptions are made about the characteristics of the electricity system. Consistent analysis of the future cost of supplying electricity in any specific electricity system can, therefore, only be obtained by sophisticated system modelling. While such modelling can calculate and compare the total system costs of different scenarios, the system interdependencies make it impossible to unambiguously allocate these costs to different types of electricity generation technologies on a per kWh basis.

Supplementary Materials: The following is available online at www.mdpi.com/1996-1073/10/3/356/s1, File S1: Input parameters for plant-level LCOE calculations.

Acknowledgments: The author acknowledges financial support from the Wuppertal Institute for Climate, Environment and Energy within the funding programme 'Open Access Publishing'.

Conflicts of Interest: The author declares no conflict of interest.

\section{References}

1. Pereira, M.G.; Sena, J.A.; Freitas, M.A.V.; da Silva, N.F. Evaluation of the impact of access to electricity: A comparative analysis of South Africa, China, India and Brazil. Renew. Sustain. Energy Rev. 2011, 15, 1427-1441. [CrossRef]

2. IEA World Energy Outlook 2016-Electricity Access Database 2016. Available online: http://www. worldenergyoutlook.org/media/weowebsite/2015/WEO2016Electricity.xlsx (accessed on 10 March 2017).

3. Key World Energy Statistics 2016; International Energy Agency: Paris, France, 2016.

4. Energy Technology Perspectives 2016-Towards Sustainable Urban Energy Systems; International Energy Agency: Paris, France, 2016.

5. Lechtenböhmer, S.; Samadi, S. The Power Sector: Pioneer and Workhouse of Decarbonization. In Decarbonization in the European Union: Internal Policies and External Strategies; Dupont, C., Ed.; Palgrave Macmillan: Basingstoke, UK, 2015; pp. 46-69.

6. Teske, S.; Sawyer, S.; Schäfer, O. Energy [r]evolution-A Sustainable World Energy Outlook 2015-100\% Renewable Energy for All; Greenpeace International, Global Wind Energy Council, SolarPower Europe: Hamburg, Germany, 2015.

7. Krey, V. Global energy-climate scenarios and models: A review. WIREs Energy Environ. 2014, 3, 363-383. [CrossRef]

8. Pfenninger, S.; Hawkes, A.; Keirstead, J. Energy systems modeling for twenty-first century energy challenges. Renew. Sustain. Energy Rev. 2014, 33, 74-86. [CrossRef]

9. Eyre, N. External costs. Energy Policy 1997, 25, 85-95. [CrossRef]

10. Dorigoni, S.; Gullí, F. Energy tax harmonization in the European Union: A proposal based on the internalization of environmental external costs. Eur. Environ. 2002, 12, 17-34. [CrossRef]

11. Streimikiene, D.; Simanaviciene, Z.; Kovaliov, R. Corporate social responsibility for implementation of sustainable energy development in Baltic States. Renew. Sustain. Energy Rev. 2009, 13, 813-824. [CrossRef] 
12. Lehmann, P.; Gawel, E. Why should support schemes for renewable electricity complement the EU emissions trading scheme? Energy Policy 2013, 52, 597-607. [CrossRef]

13. Christensen, J.M.; Halsnæs, K.; Sathaye, J. Mitigation and Adaptation Cost Assessment: Concepts, Methods and Appropriate Use; Risø National Laboratory, UNEP Collaborating Centre on Energy and Environment: Roskilde, Denmark, 1998.

14. Hirth, L.; Ueckerdt, F.; Edenhofer, O. Integration costs revisited-An economic framework for wind and solar variability. Renew. Energy 2015, 74, 925-939. [CrossRef]

15. Wang, Y.; Brown, M.A. Policy drivers for improving electricity end-use efficiency in the USA: An economic-engineering analysis. Energy Effic. 2014, 7, 517-546. [CrossRef]

16. Hoffman, I.M.; Rybka, G.M.; Leventis, G.; Goldman, C.A.; Schwartz, L.C.; Billingsley, M.A.; Schiller, S.R. The Total Cost of Saving Electricity through Utility Customer-Funded Energy Efficiency Programs: Estimates at the National, State, Sector and Program Level; Lawrence Berkeley National Laboratory: Berkeley, CA, USA, 2015.

17. Levy, J.I.; Woo, M.K.; Penn, S.L.; Omary, M.; Tambouret, Y.; Kim, C.S.; Arunachalam, S. Carbon reductions and health co-benefits from US residential energy efficiency measures. Environ. Res. Lett. 2016, 11. [CrossRef]

18. Cossent, R.; Gómez, T.; Frías, P. Towards a future with large penetration of distributed generation: Is the current regulation of electricity distribution ready? Regulatory recommendations under a European perspective. Energy Policy 2009, 37, 1145-1155. [CrossRef]

19. Lehmann, P.; Creutzig, F.; Ehlers, M.-H.; Friedrichsen, N.; Heuson, C.; Hirth, L.; Pietzcker, R. Carbon lock-out: Advancing renewable energy policy in Europe. Energies 2012, 5, 323-354. [CrossRef]

20. Swider, D.J.; Beurskens, L.; Davidson, S.; Twidell, J.; Pyrko, J.; Prüggler, W.; Auer, H.; Vertin, K.; Skema, R. Conditions and costs for renewables electricity grid connection: Examples in Europe. Renew. Energy 2008, 33, 1832-1842. [CrossRef]

21. International Renewable Energy Agency (IRENA). Renewable Power Generation Costs in 2014; IRENA: Abu Dhabi, UAE, 2015.

22. Wiser, R.; Yang, Z.; Hand, M.; Hohmeyer, O.; Infield, D.; Jensen, P.H.; Nikolaev, V.; O'Malley, M.; Sinden, G.; Zervos, A. Wind Energy. In IPCC Special Report on Renewable Energy Sources and Climate Change Mitigation; Edenhofer, O., Pichs-Madruga, R., Sokona, Y., Seyboth, K., Matschoss, P., Kadner, S., Zwickel, T., Eickemeier, P., Hansen, G., Schlömer, S., et al., Eds.; Cambridge University Press: Cambridge, UK; New York, NY, USA, 2011.

23. International Energy Agency (IEA). Projected Costs of Generating Electricity: 2010 Edition; IEA: Paris, France, 2010.

24. International Energy Agency (IEA). Projected Costs of Generating Electricity: 2015 Edition; IEA: Paris, France, 2015.

25. International Energy Agency (IEA). World Energy Outlook 2011; Organisation for Economic Co-Operation and Development (OECD): Paris, France, 2011.

26. Valente, S. Intergenerational externalities, sustainability and welfare-The ambiguous effect of optimal policies on resource depletion. Resour. Energy Econ. 2011, 33, 995-1014. [CrossRef]

27. World Bank; Ecofys; Vivid Economics. State and Trends of Carbon Pricing 2016; World Bank: Washington, DC, USA, 2016.

28. Ruf, P.; Ehrmann, V.; Ahrens, J. Options to Strengthen the EU ETS; EURELECTRIC: Karlsruhe, Germany, 2016; p. 42.

29. Government of Canada. Pan-Canadian Framework on Clean Growth and Climate Change-Canada's Plan to Address Climate Change and Grow the Economy 2016; Government of Canada: Ottawa, ON, Canada, 2016.

30. Williams, J.H.; Haley, B.; Kahrl, F.; Moore, J.; Jones, A.; Torn, M.; McJeon, H. Pathways to Deep Decarbonization in the United States; Energy and Environmental Economics, Inc. (E3): San Francisco, CA, USA, 2014.

31. Lazard. Lazard's Levelized Cost of Energy Analysis, version 10.0; Lazard: New York, NY, USA, 2016.

32. Fischedick, M.; Schaeffer, R.; Adedoyin, A.; Akai, M.; Bruckner, T.; Clarke, L.; Krey, V.; Savolainen, I.; Teske, S.; Ürge-Vorsatz, D.; et al. Mitigation Potential and Costs. In IPCC Special Report on Renewable Energy Sources and Climate Change Mitigation; Edenhofer, O., Ed.; Cambridge University Press: Cambridge, UK, 2011; pp. 791-864.

33. International Energy Agency (IEA). World Energy Outlook 2016; Organisation for Economic Co-Operation and Development (OECD): Paris, France, 2016. 
34. U.S. Energy Information Administration. Capital Cost Estimates for Utility Scale Electricity Generating Plants; U.S. Energy Information Administration: Washington, DC, USA, 2016.

35. Schröder, A.; Kunz, F.; Meiss, J.; Mendelevitch, R.; von Hirschhausen, C. Current and Prospective Costs of Electricity Generation until 2050; German Institute for Economic Research: Berlin, Germany, 2013.

36. Lévy, J.-B.; Ursat, X. EDF, A responsible electricity company, a champion of low carbon energy growth. Presented at the EDF Press Conference, Paris, France, 3 September 2015.

37. Rankin, J. Flamanville: France's beleaguered forerunner to Hinkley Point C. In The Guardian 2016; Guardian News \& Media: London, UK, 2016.

38. International Renewable Energy Agency (IRENA). Renewable Power Generation Costs in 2016; IRENA: Abu Dhabi, UAE, 2017, forthcoming.

39. Moné, C.; Stehly, T.; Maples, B.; Settle, E. 2014 Cost of Wind Energy Review; National Renewable Energy Laboratory: Golden, CO, USA, 2015.

40. International Renewable Energy Agency (IRENA). The Power to Change: Solar and Wind Cost Reduction Potential to 2025; IRENA: Bonn, Germany, 2016.

41. The European Wind Energy Association (EWEA). Wind in Power-2015 European Statistics; The European Wind Energy Association: Brussels, Belgium, 2016.

42. Vartiainen, E.; Masson, G.; Breyer, C. PV LCOE in Europe 2014-30; European Photovoltaic Technology Platform: Munich, Germany, 2015.

43. Bolinger, M.; Seel, J. Utility-Scale Solar 2015: An Empirical Analysis of Project Cost, Performance, and Pricing Trends in the United States; Lawrence Berkeley National Laboratory: Berkeley, CA, USA, 2016.

44. U.S. Energy Information Administration. Electric Power Monthly with Data for October 2016; U.S. Energy Information Administration: Washington, DC, USA, 2016.

45. Caplin, A.; Leahy, J. The Social Discount Rate; National Bureau of Economic Research: Cambridge, MA, USA, 2000.

46. Moore, M.A.; Boardman, A.E.; Vining, A.R.; Weimer, D.L.; Greenberg, D.H. "Just give me a number!" Practical values for the social discount rate. J. Policy Anal. Manag. 2004, 23, 789-812. [CrossRef]

47. Hirth, L.; Steckel, J.C. The role of capital costs in decarbonizing the electricity sector. Environ. Res. Lett. 2016, 11. [CrossRef]

48. Awerbuch, S. Portfolio-Based Electricity Generation planning: Policy implications for renewables and energy security. Mitig. Adapt. Strateg. Glob. Chang. 2006, 11, 693-710. [CrossRef]

49. Roland Berger. Offshore Wind Power: Takeaways from the Borssele Wind Farm; Think Act: Munich, Germany, 2016.

50. International Energy Agency (IEA). Harnessing Variable Renewables: A Guide to the Balancing Challenge; IEA: Paris, France, 2011.

51. Ueckerdt, F.; Hirth, L.; Luderer, G.; Edenhofer, O. System LCOE: What are the costs of variable renewables? Energy 2013, 63, 61-75. [CrossRef]

52. Hirth, L. The benefits of flexibility: The value of wind energy with hydropower. Appl. Energy 2016, 181, 210-223. [CrossRef]

53. Hirth, L. The market value of variable renewables: The effect of solar wind power variability on their relative price. Energy Econ. 2013, 38, 218-236. [CrossRef]

54. Holttinen, H.; Meibom, P.; Orths, A.; Lange, B.; O’Malley, M.; Tande, J.O.; Estanqueiro, A.; Gomez, E.; Söder, L.; Strbac, G.; et al. Impacts of large amounts of wind power on design and operation of power systems, results of IEA collaboration. Wind Energy 2011, 14, 179-192. [CrossRef]

55. Auer, H.; Huber, C.; Faber, T.; Resch, G.; Obersteiner, C.; Weissensteiner, L.; Haas, R. Economics of large-scale intermittent RES-E integration into the European grids: Analyses based on the simulation software GreenNet. Int. J. Glob. Energy Issues 2006, 25, 219-242. [CrossRef]

56. Schaber, K.; Steinke, F.; Hamacher, T. Transmission grid extensions for the integration of variable renewable energies in Europe: Who benefits where? Energy Policy 2012, 43, 123-135. [CrossRef]

57. Mills, A.; Wiser, R.; Porter, K. The cost of transmission for wind energy in the United States: A review of transmission planning studies. Renew. Sustain. Energy Rev. 2012, 16, 1-19. [CrossRef]

58. Keppler, J.H.; Cometto, M. Nuclear Energy and Renewables: System Effects in Low-Carbon Electricity Systems; Nuclear Energy Agency, OECD: Paris, France, 2012. 
59. Pudjianto, D.; Djapic, P.; Dragovic, J.; Strbac, G. Grid Integration Cost of PhotoVoltaic Power Generation; Energy Futures Lab, Imperial College: London, UK, 2013.

60. Hou, W.; Allinson, G.; MacGill, I.; Neal, P.; Ho, M. Cost comparison of major low-carbon electricity generation options: An Australian case study. Sustain. Energy Technol. Assess. 2014, 8, 131-148. [CrossRef]

61. Brouwer, A.S.; van den Broek, M.; Seebregts, A.; Faaij, A. Impacts of large-scale Intermittent Renewable Energy Sources on electricity systems, and how these can be modeled. Renew. Sustain. Energy Rev. 2014, 33, 443-466. [CrossRef]

62. Milligan, M.R.; Kirby, B. Calculating Wind Integration Costs: Separating Wind Energy Value from Integration Cost Impacts; National Renewable Energy Laboratory: Golden, CO, USA, 2009.

63. Mason, T.; Curry, T.; Hong, M.; Benson, J.; Olson, S.; Sprouse, M.; Wilson, D. Solar Photovoltaic (PV) Integration Cost Study; Black \& Veatch: Overland Park, KS, USA, 2012.

64. Holttinen, H.; Kiviluoma, J.; Robitaille, A.; Cutululis, N.A.; Orths, A.; van Hulle, F.; Pineda, I.; Lange, B.; O'Malley, M.; Dillon, J.; et al. Design and Operation of Power Systems with Large Amounts of Wind Power; IEA WIND Task 25; VTT Technology: Espoo, Finland, 2013; p. 81.

65. International Energy Agency (IEA). The Power of Transformation-Wind, Sun and the Economics of Flexible Power Systems; IEA: Paris, France, 2014.

66. Deetjen, T.A.; Garrison, J.B.; Rhodes, J.D.; Webber, M.E. Solar PV integration cost variation due to array orientation and geographic location in the Electric Reliability Council of Texas. Appl. Energy 2016, 180, 607-616. [CrossRef]

67. Silva, A.R.; Pimenta, F.M.; Assireu, A.T.; Spyrides, M.H.C. Complementarity of Brazil's hydro and offshore wind power. Renew. Sustain. Energy Rev. 2016, 56, 413-427. [CrossRef]

68. International Renewable Energy Agency (IRENA). Renewable Energy Market Analysis: Latin America; IRENA: Abu Dhabi, UAE, 2016.

69. Agora Energiewende. The Integration Cost of Wind and Solar Power. An Overview of the Debate on the Effects of Adding Wind and Solar Photovoltaic into Power Systems; Agora Energiewende: Berlin, Germany, 2015.

70. Ghofrani, M.; Arabali, A.; Etezadi-Amoli, M.; Fadali, M.S. Smart scheduling and cost-benefit analysis of grid-enabled electric vehicles for wind power integration. IEEE Trans. Smart Grid 2014, 5, 2306-2313. [CrossRef]

71. Gils, H.C. Economic potential for future demand response in Germany-Modeling approach and case study. Appl. Energy 2016, 162, 401-415. [CrossRef]

72. Hirth, L.; Müller, S. System-friendly wind power: How advanced wind turbine design can increase the economic value of electricity generated through wind power. Energy Econ. 2016, 56, 51-63. [CrossRef]

73. Söderholm, P.; Sundqvist, T. Pricing environmental externalities in the power sector: Ethical limits and implications for social choice. Ecol. Econ. 2003, 46, 333-350. [CrossRef]

74. Dalianis, D.; Petassis, D.; Santamouris, M.; Argiriou, A.; Cartalis, C.; Asimakopoulos, D.N. Social cost of electricity generation in Greece. Renew. Energy 1997, 12, 281-289. [CrossRef]

75. Karimzadegan, H.; Rahmatian, M.; Farsiabi, M.M.; Meiboudi, H. Social cost of fossil-based electricity generation plants in Iran. Environ. Eng. Manag. J. 2015, 14, 2373-2381.

76. Tol, R.S.J. The economic effects of climate change. J. Econ. Perspect. 2009, 23, 29-51. [CrossRef]

77. Anthoff, D. Report on Marginal External Damage Costs of Greenhouse Gas Emissions. Available online: http:/ / www.needs-project.org/2009/Deliverables/RS1b\%20D5.4-5.5.pdf (accessed on 7 March 2017).

78. Fabert, B.P.; Dumas, P.; Hourcade, J.-C. What Social Cost of Carbon? A Mapping of the Climate Debate; Social Science Research Network: Rochester, NY, USA, 2012.

79. Van den Bergh, J.C.J.M.; Botzen, W.J.W. Monetary valuation of the social cost of $\mathrm{CO}_{2}$ emissions: A critical survey. Ecol. Econ. 2015, 114, 33-46. [CrossRef]

80. Van den Bergh, J.C.J.M.; Botzen, W.J.W. A lower bound to the social cost of $\mathrm{CO}_{2}$ emissions. Nat. Clim. Chang. 2014, 4, 253-258. [CrossRef]

81. Watkiss, P.; Downing, T. The social cost of carbon: Valuation estimates and their use in UK policy. Integr. Assess. 2008, 8, 85-105.

82. Interagency Working Group on Social Cost of Carbon. Technical Update of the Social Cost of Carbon for Regulatory Impact Analysis-Under Executive Order 12866. Available online: https:/ / obamawhitehouse. archives.gov/sites/default/files/omb/inforeg/scc-tsd-final-july-2015.pdf (accessed on 7 March 2017).

83. Tol, R.S.J. Targets for global climate policy: An overview. J. Econ. Dyn. Control 2013, 37, 911-928. [CrossRef] 
84. Ackerman, F.; Stanton, E.A. Climate risks and carbon prices: Revising the social cost of carbon. Economics 2012, 6, 1-25. [CrossRef]

85. Moore, F.C.; Diaz, D.B. Temperature impacts on economic growth warrant stringent mitigation policy. Nat. Clim. Chang. 2015, 5, 127-131. [CrossRef]

86. Revesz, R.L.; Howard, P.H.; Arrow, K.; Goulder, L.H.; Kopp, R.E.; Livermore, M.A.; Oppenheimer, M.; Sterner, T. Global warming: Improve economic models of climate change. Nat. News 2014, 508, 173. [CrossRef]

87. Weitzman, M.L. Tail-hedge discounting and the social cost of carbon. J. Econ. Lit. 2013, 51, 873-882. [CrossRef]

88. Stern, N. The structure of economic modeling of the potential impacts of climate change: Grafting gross underestimation of risk onto already narrow science models. J. Econ. Lit. 2013, 51, 838-859. [CrossRef]

89. Tol, R.S.J. The social cost of carbon. Annu. Rev. Resour. Econ. 2011, 3, 419-443. [CrossRef]

90. Kopp, R.E.; Golub, A.; Keohane, N.O.; Golub, A.; Keohane, N.O.; Onda, C. The Influence of the specification of climate change damages on the social cost of carbon. Economics 2012, 6, 1-40. [CrossRef]

91. Lenton, T.M.; Ciscar, J.-C. Integrating tipping points into climate impact assessments. Clim. Chang. 2013, 117, 585-597. [CrossRef]

92. Weitzman, M.L. Fat-tailed uncertainty in the economics of catastrophic climate change. Rev. Environ. Econ. Policy 2011, 5, 275-292. [CrossRef]

93. Fischedick, M.; Esken, A.; Pastowski, A.; Schüwer, D.; Supersberger, N.; Nitsch, J.; Viebahn, P.; Bandi, A.; Zuberbühler, U.; Edenhofer, O. RECCS: Ecological, Economic and Structural Comparison of Renewable Energy Technologies (RE) with Carbon Capture and Storage (CCS)—An Integrated Approach; Federal Ministry for the Environment, Nature Conservation and Nuclear Safety: Wuppertal, Germany, 2008.

94. Sathaye, J.; Lucon, O.; Rahman, A.; Christensen, J.; Denton, F.; Fujino, J.; Heath, G.; Kadner, S.; Mirza, M.; Rudnick, H.; et al. Renewable Energy in the Context of Sustainable Development. In IPCC Special Report on Renewable Energy Sources and Climate Change Mitigation; Edenhofer, O., Pichs-Madruga, R., Sokona, Y., Seyboth, K., Matschoss, P., Kadner, S., Zwickel, T., Eickemeier, P., Hansen, G., Schlömer, S., et al., Eds.; Cambridge University Press: Cambridge, UK; New York, NY, USA, 2011.

95. Warner, E.S.; Heath, G.A. Life cycle greenhouse gas emissions of nuclear electricity generation. J. Ind. Ecol. 2012, 16, S73-S92. [CrossRef]

96. National Research Council. Hidden Costs of Energy: Unpriced Consequences of Energy Production and Use; The National Academies Press: Washington, DC, USA, 2010.

97. European Environment Agency. European Union Emission Inventory Report 1990-2014 under the UNECE Convention on Long-Range Transboundary Air Pollution (LRTAP); European Environment Agency: Copenhagen, Denmark, 2016.

98. Anderson, J.O.; Thundiyil, J.G.; Stolbach, A. Clearing the air: A review of the effects of particulate matter air pollution on human health. J. Med. Toxicol. 2012, 8, 166-175. [CrossRef] [PubMed]

99. Gauderman, W.J.; Avol, E.; Gilliland, F.; Vora, H.; Thomas, D.; Berhane, K.; McConnell, R.; Kuenzli, N.; Lurmann, F.; Rappaport, E.; et al. The Effect of air pollution on lung development from 10 to 18 years of age. N. Engl. J. Med. 2004, 351, 1057-1067. [CrossRef] [PubMed]

100. Kim, K.-H.; Kabir, E.; Kabir, S. A review on the human health impact of airborne particulate matter. Environ. Int. 2015, 74, 136-143. [CrossRef] [PubMed]

101. Pope, C.A.; Burnett, R.T.; Thun, M.J.; Calle, E.E.; Krewski, D.; Ito, K.; Thurston, G.D. Lung cancer, cardiopulmonary mortality, and long-term exposure to fine particulate air pollution. JAMA 2002, 287, 1132-1141. [CrossRef] [PubMed]

102. Pope, C.A.; Dockery, D.W. Health effects of fine particulate air pollution: Lines that connect. J. Air Waste Manag. Assoc. 2006, 56, 709-742. [CrossRef] [PubMed]

103. Sousa, S.I.V.; Alvim-Ferraz, M.C.M.; Martins, F.G. Health effects of ozone focusing on childhood asthma: What is now known-A review from an epidemiological point of view. Chemosphere 2013, 90, 2051-2058. [CrossRef] [PubMed]

104. United Nations Environment Programme (UNEP). Global Mercury Assessment 2013: Sources, Emissions, Releases and Environmental Transport; UNEP Chemicals Branch: Geneva, Switzerland, 2013; p. 42.

105. Preiss, P.; Roos, J.; Friedrich, R. Assessment of Health Impacts of Coal Fired Power Stations in Germany; Institute for Energy Economics and the Rational Use of Energy (IER): Stuttgart, Germany, 2013. 
106. Torfs, R.; Hurley, F.; Miller, B.; Rabl, A. A Set of Concentration-Response Functions. Available online: http:/ / www.needs-project.org/2009/Deliverables/Rs1b\%20D3.7.pdf (accessed on 10 March 2017).

107. External Costs from Emerging Electricity Generation Technologies. Available online: http:/ /www.needsproject.org/docs/RS1a\%20D6_1\%20External\%20costs\%20of\%20reference\%20technologies\%2024032009. pdf (accessed on 10 March 2017).

108. Epstein, P.R.; Buonocore, J.J.; Eckerle, K.; Hendryx, M.; Stout, B.M., III; Heinberg, R.; Clapp, R.W.; May, B.; Reinhart, N.L.; Ahern, M.M.; et al. Full cost accounting for the life cycle of coal. Ann. N. Y. Acad. Sci. 2011, 1219, 73-98. [CrossRef] [PubMed]

109. Schwartz, J.; Coull, B.; Laden, F.; Ryan, L. The effect of dose and timing of dose on the association between airborne particles and survival. Environ. Health Perspect. 2008, 116, 64-69. [CrossRef] [PubMed]

110. Machol, B.; Rizk, S. Economic value of U.S. fossil fuel electricity health impacts. Environ. Int. 2013, 52, 75-80. [CrossRef] [PubMed]

111. Hoen, B.; Brown, J.P.; Jackson, T.; Thayer, M.A.; Wiser, R.; Cappers, P. Spatial hedonic analysis of the effects of us wind energy facilities on surrounding property values. J. Real Estate Financ. Econ. 2015, 51, $22-51$. [CrossRef]

112. Hoen, B.; Atkinson-Palombo, C. Wind turbines, amenities and disamenities: A study of home value impacts in densely populated Massachusetts. J. Real Estate Res. 2016, 38, 473-504.

113. Lang, C.; Opaluch, J.J.; Sfinarolakis, G. The windy city: Property value impacts of wind turbines in an urban setting. Energy Econ. 2014, 44, 413-421. [CrossRef]

114. Laposa, S.; Mueller, A. Wind farm announcements and rural home prices: Maxwell ranch and rural northern Colorado. J. Sustain. Real Estate 2010, 2, 383-402.

115. Dröes, M.I.; Koster, H.R.A. Renewable energy and negative externalities: The effect of wind turbines on house prices. J. Urban Econ. 2016, 96, 121-141. [CrossRef]

116. Gibbons, S. Gone with the wind: Valuing the visual impacts of wind turbines through house prices. J. Environ. Econ. Manag. 2015, 72, 177-196. [CrossRef]

117. Sunak, Y.; Madlener, R. The impact of wind farm visibility on property values: A spatial difference-indifferences analysis. Energy Econ. 2016, 55, 79-91. [CrossRef]

118. Sunak, Y.; Madlener, R. The impact of wind farms on property values: A locally weighted hedonic pricing model. Pap. Reg. Sci. 2015. [CrossRef]

119. Krueger, A.D.; Parsons, G.R.; Firestone, J. Valuing the visual disamenity of offshore wind power projects at varying distances from the shore: An application on the delaware shoreline. Land Econ. 2011, 87, 268-283. [CrossRef]

120. Ladenburg, J.; Lutzeyer, S. The economics of visual disamenity reductions of offshore wind farms-Review and suggestions from an emerging field. Renew. Sustain. Energy Rev. 2012, 16, 6793-6802. [CrossRef]

121. Meyerhoff, J.; Ohl, C.; Hartje, V. Landscape externalities from onshore wind power. Energy Policy 2010, 38, 82-92. [CrossRef]

122. Westerberg, V.; Jacobsen, J.B.; Lifran, R. The case for offshore wind farms, artificial reefs and sustainable tourism in the French mediterranean. Tour. Manag. 2013, 34, 172-183. [CrossRef]

123. Mirasgedis, S.; Tourkolias, C.; Tzovla, E.; Diakoulaki, D. Valuing the visual impact of wind farms: An application in South Evia, Greece. Renew. Sustain. Energy Rev. 2014, 39, 296-311. [CrossRef]

124. Schleisner, L.; Sieverts Nielsen, P. External Costs Related to Power Production Technologies; Externe National Implementation for Denmark; Risoe National Lab.: Roskilde, Denmark, 1997.

125. Chiang, A.C.; Keoleian, G.A.; Moore, M.R.; Kelly, J.C. Investment cost and view damage cost of siting an offshore wind farm: A spatial analysis of Lake Michigan. Renew. Energy 2016, 96, 966-976. [CrossRef]

126. Markandya, A.; Bigano, A.; Porchia, R. The Social Cost of Electricity: Scenarios and Policy Implications; Edward Elgar Publishing Ltd.: Cheltenham, UK; Northampton, MA, USA, 2011.

127. Lewis, L.Y.; Bohlen, C.; Wilson, S. Dams, dam removal, and river restoration: A hedonic property value analysis. Contemp. Econ. Policy 2008, 26, 175-186. [CrossRef]

128. Bohlen, C.; Lewis, L.Y. Examining the economic impacts of hydropower dams on property values using GIS. J. Environ. Manag. 2009, 90 (Suppl. S3), S258-S269. [CrossRef] [PubMed]

129. Provencher, B.; Sarakinos, H.; Meyer, T. Does small dam removal affect local property values? An empirical analysis. Contemp. Econ. Policy 2008, 26, 187-197. [CrossRef] 
130. McKean, J.R.; Johnson, D.; Taylor, R.G.; Johnson, R. Willingness to pay for non angler recreation at the lower Snake River reservoirs. J. Leis. Res. 2005, 37, 178-194.

131. Rolfe, J.; Prayaga, P. Estimating values for recreational fishing at freshwater dams in Queensland. Aust. J. Agric. Resour. Econ. 2007, 51, 157-174. [CrossRef]

132. Loomis, J.B. Measuring the economic benefits of removing dams and restoring the elwha river: Results of a contingent valuation survey. Water Resour. Res. 1996, 32, 441-447. [CrossRef]

133. Getzner, M. Importance of free-flowing rivers for recreation: Case study of the River Mur in Styria, Austria. J. Water Resour. Plan. Manag. 2015, 141, 04014050. [CrossRef]

134. Ricci, A. Annex-A Summary Account of the Final Debate. Available online: http://www.needs-project. org/docs/Annexstampa.pdf (accessed on 10 March 2017).

135. Nordhaus, W. Estimates of the social cost of carbon: Concepts and results from the DICE-2013R Model and alternative approaches. J. Assoc. Environ. Resour. Econ. 2014, 1, 273-312. [CrossRef]

136. Sovacool, B.K. Contextualizing avian mortality: A preliminary appraisal of bird and bat fatalities from wind, fossil-fuel, and nuclear electricity. Energy Policy 2009, 37, 2241-2248. [CrossRef]

137. Willis, C.K.R.; Barclay, R.M.R.; Boyles, J.G.; Mark Brigham, R.; Brack, V., Jr.; Waldien, D.L.; Reichard, J. Bats are not birds and other problems with Sovacool's (2009) analysis of animal fatalities due to electricity generation. Energy Policy 2010, 38, 2067-2069. [CrossRef]

138. Ho, C.K. Review of avian mortality studies at concentrating solar power plants. In AIP Conference Proceedings; AIP Publishing: Melville, NY, USA, 2016; Volume 1734, p. 070017.

139. Walston, L.J., Jr.; Rollins, K.E.; LaGory, K.E.; Smith, K.P.; Meyers, S.A. A preliminary assessment of avian mortality at utility-scale solar energy facilities in the United States. Renew. Energy 2016, 92, 405-414. [CrossRef]

140. Burgherr, P.; Hirschberg, S. Comparative risk assessment of severe accidents in the energy sector. Energy Policy 2014, 74 (Suppl. S1), S45-S56. [CrossRef]

141. Friedrich, R.; Rabl, A.; Hirschberg, S.; Desaigues, B.; Markandya, A.; de Nocker, L. New elements for the assessment of external costs from energy technologies. In EU 5th Framework Programme; Institute for Energy Economics and the Rational Use of Energy: Stuttgart, Germany, 2004.

142. ExternE: Externalities of Energy: Methodology 2005 Update; Bickel, P.; Friedrich, R., Eds.; Office for Official Publications of the European Communities: Luxembourg, 2005.

143. Eeckhoudt, L.; Schieber, C.; Schneider, T. Risk aversion and the external cost of a nuclear accident. J. Environ. Manag. 2000, 58, 109-117. [CrossRef]

144. Markandya, A.; Dale, N.; Schneider, T. Improvement of the Assessment of the External Costs of Severe Nuclear Accidents; Centre d'Etude sur l'Evaluation de la Protection dans le Domaine Nucleaire: Fontenay-aux-Roses, France, 1998.

145. OECD; Nuclear Energy Agency. Nuclear Electricity Generation: What Are the External Costs? OECD: Paris, France, 2003.

146. Rabl, A.; Rabl, V.A. External costs of nuclear: Greater or less than the alternatives? Energy Policy 2013, 57, 575-584. [CrossRef]

147. Burtraw, D.; Krupnick, A.; Sampson, G.; Beasley, B. The True Cost of Electric Power-An Inventory of Methodologies to Support Future Decisionmaking in Comparing the Cost and Competitiveness of Electricity Generation Technologies; Resources for the Future: Washington, DC, USA, 2012.

148. Laes, E.; Meskens, G.; van der Sluijs, J.P. On the contribution of external cost calculations to energy system governance: The case of a potential large-scale nuclear accident. Energy Policy 2011, 39, 5664-5673. [CrossRef]

149. Arnold, S.; Hunt, A. National and EU-Level Estimates of Energy Supply Externalities; Centre for European Policy Studies (CEPS): Brussels, Belgium, 2009.

150. Markandya, A.; Pemberton, M. Energy security, energy modelling and uncertainty. Energy Policy 2010, 38, 1609-1613. [CrossRef]

151. Valentine, S.V. Emerging symbiosis: Renewable energy and energy security. Renew. Sustain. Energy Rev. 2011, 15, 4572-4578. [CrossRef]

152. Mathur, H.M. Displacement and Resettlement in India: The Human Cost of Development; Routledge: Abingdon, UK, 2013; Volume 69.

153. Owen, J.R.; Kemp, D. Mining-induced displacement and resettlement: A critical appraisal. J. Clean. Prod. 2015, 87, 478-488. [CrossRef] 
154. Scudder, T. Resettlement Outcomes of Large Dams. In Impacts of Large Dams: A Global Assessment; Tortajada, C., Altinbilek, D., Biswas, A.K., Eds.; Water Resources Development and Management; Springer: Berlin/Heidelberg, Germany, 2012; pp. 37-67.

155. Sovacool, B.K.; Bulan, L.C. Behind an ambitious megaproject in Asia: The history and implications of the Bakun hydroelectric dam in Borneo. Energy Policy 2011, 39, 4842-4859. [CrossRef]

156. Kronenberg, T. Should we worry about the failure of the hotelling rule? J. Econ. Surv. 2008, 22, 774-793. [CrossRef]

157. Reynolds, D.B. Uncertainty in exhaustible natural resource economics: The irreversible sunk costs of Hotelling. Resour. Policy 2013, 38, 532-541. [CrossRef]

158. Schilling, M.; Chiang, L. The effect of natural resources on a sustainable development policy: The approach of non-sustainable externalities. Energy Policy 2011, 39, 990-998. [CrossRef]

159. Masanet, E.; Chang, Y.; Gopal, A.R.; Larsen, W.P., III; Sathre, R.; Shehabi, A.; Zhai, P. Life-cycle assessment of electric power systems. Annu. Rev. Environ. Resour. 2013, 38, 107-136. [CrossRef]

160. Grünthal, G. Induced seismicity related to geothermal projects versus natural tectonic earthquakes and other types of induced seismic events in Central Europe. Geothermics 2014, 52, 22-35. [CrossRef]

161. Ek, K.; Persson, L. Wind farms-Where and how to place them? A choice experiment approach to measure consumer preferences for characteristics of wind farm establishments in Sweden. Ecol. Econ. 2014, 105, 193-203. [CrossRef]

162. Dastrup, S.R.; Graff Zivin, J.; Costa, D.L.; Kahn, M.E. Understanding the Solar Home price premium: Electricity generation and "Green" social status. Eur. Econ. Rev. 2012, 56, 961-973. [CrossRef]

163. Blazejczak, J.; Diekmann, J.; Edler, D.; Kemfert, C.; Neuhoff, K.; Schill, W.-P. Energiewende Erfordert Hohe Investitionen; DIW Wochenbericht; DIW: Berlin, Germany, 2013; pp. 19-30.

164. Grubler, A. The costs of the French nuclear scale-up: A case of negative learning by doing. Energy Policy 2010, 38, 5174-5188. [CrossRef]

165. Lovering, J.R.; Yip, A.; Nordhaus, T. Historical construction costs of global nuclear power reactors. Energy Policy 2016, 91, 371-382. [CrossRef]

166. Escobar Rangel, L.; Lévêque, F. Revisiting the Nuclear Power Construction Costs Escalation Curse. Available online: http:/ / www.iaee.org/en/publications / fullnewsletter.aspx?id=27 (accessed on 10 March 2017).

167. Sensfuß, F.; Pfluger, B. Optimized Pathways towards Ambitious Climate Protection in the European Electricity System (EU Long-Term Scenarios 2050 II); Fraunhofer ISI: Karlsruhe, Germany, 2014.

168. Akbilgic, O.; Doluweera, G.; Mahmoudkhani, M.; Bergerson, J. A meta-analysis of carbon capture and storage technology assessments: Understanding the driving factors of variability in cost estimates. Appl. Energy 2015, 159, 11-18. [CrossRef]

(C) 2017 by the author. Licensee MDPI, Basel, Switzerland. This article is an open access article distributed under the terms and conditions of the Creative Commons Attribution (CC BY) license (http://creativecommons.org/licenses/by/4.0/). 